
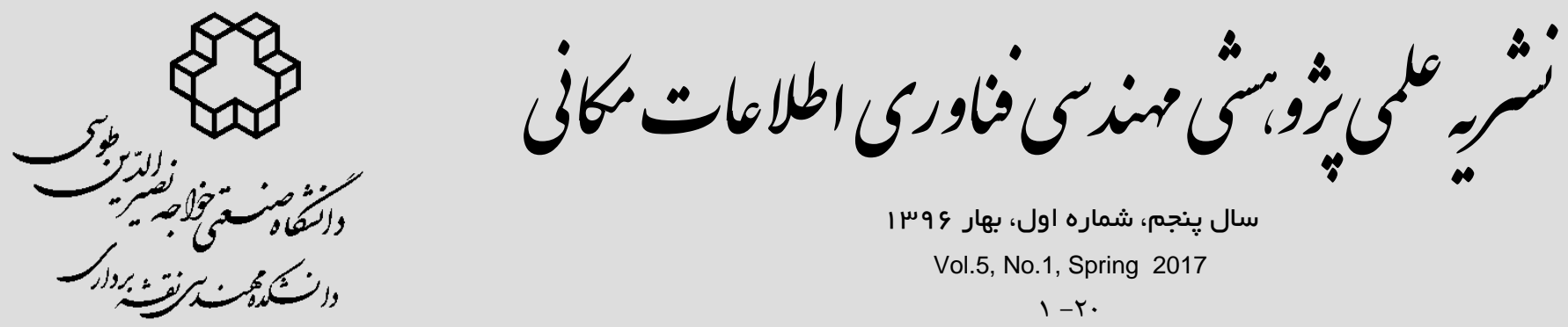

سال ينجم، شماره اول، بهار و

Vol.5, No.1, Spring 2017

$1-r$.

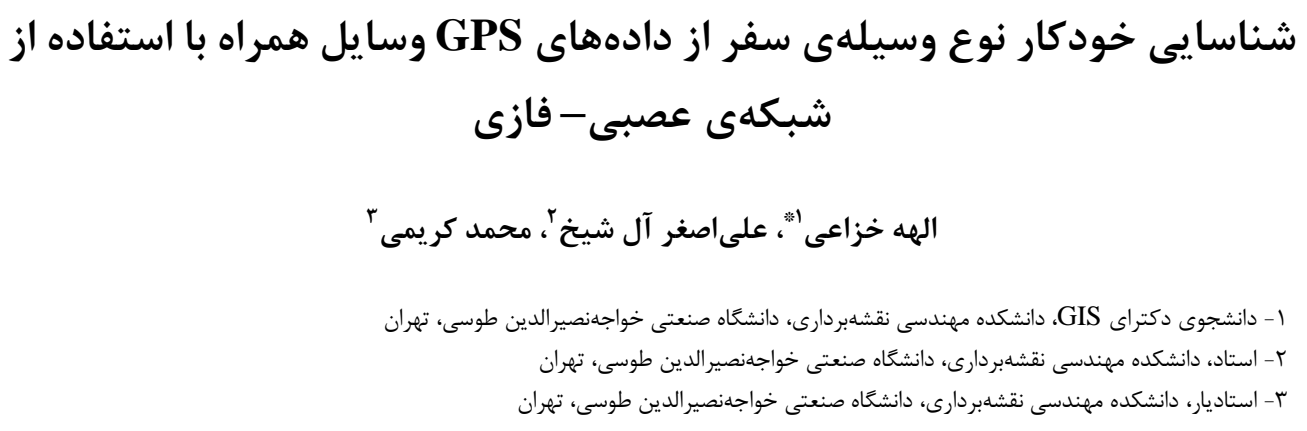

تاريخ دريافت مقاله:

جكيده

تعيين نوع و تقاضاى سفر اهميت زيادى در سازمانهاى حمل و نقل هر كشور دارد. با تشخيص دقيق نوع وسيلهى سفر هر كاربر،

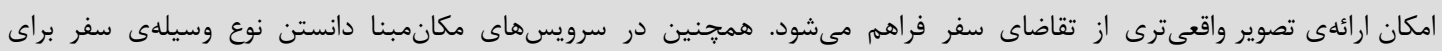

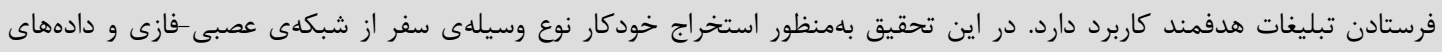

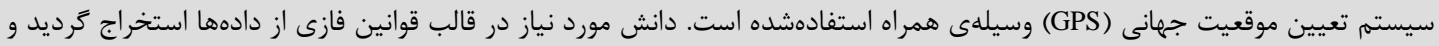

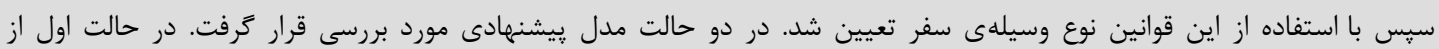

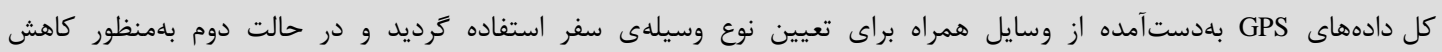

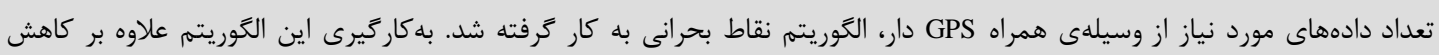

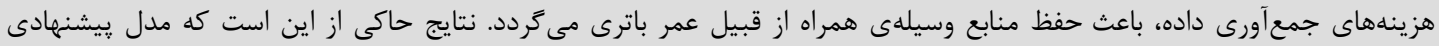

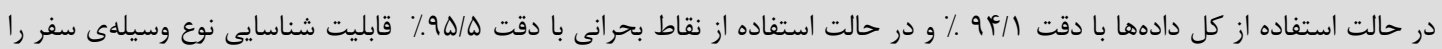
دارا مىباشد.

كليد وازهها : شبكهى عصبى - فازى، شناسايى نوع وسيلهى سفر، نقاط بحرانى، دادهاى GPS. 
سيستم تعيين موقعيت جهانى (GPS) ه وسيلهى نقليه

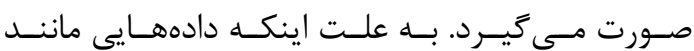

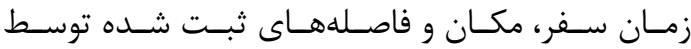

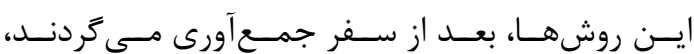

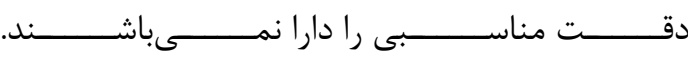

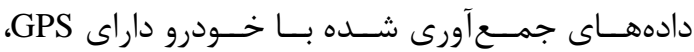

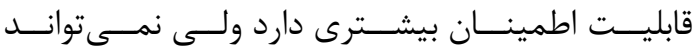

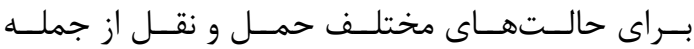

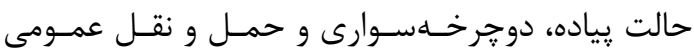

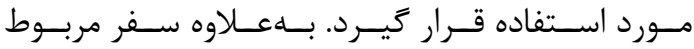

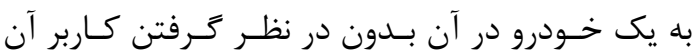

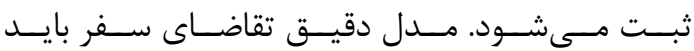

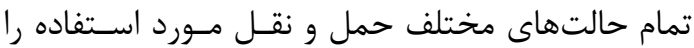
شامل شود [9]. GPS مسى توانـد مكــان دقيـق، زمـان و و

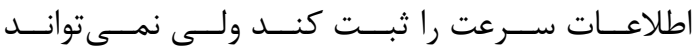

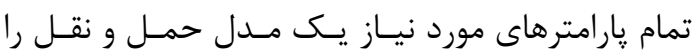

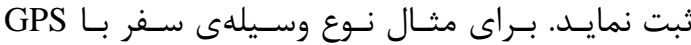

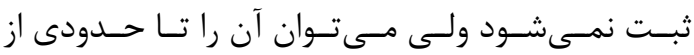
دادههاى GPS استخراج نمود [9]. مطالعاتى كه هدفشان استنتاج حالت سفر باشد را

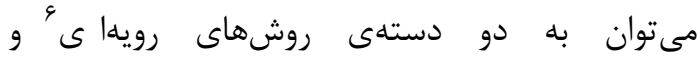

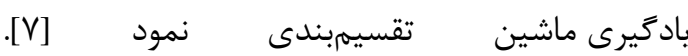
در روشهاى رويهاى تلاش عمدتاً به استنتاج بر اساس نماس مفروضات منطقى است؛ مانند اين كه جكونه يك شخص معمولى ممكن است سفر كند. مثال ديخر مىتواند مفروضاتى از قبيل نزديكترين شبكدى حمل و نقل كه محيط اطراف را در بر مى كيرد باشد. در روشهاى

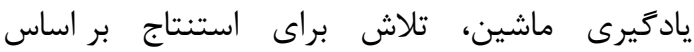

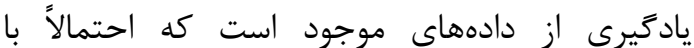
ييشفرضهاى منطقى مشابه تركيب شدهاند [V].

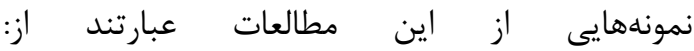

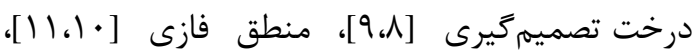

\footnotetext{
${ }^{5}$ Global Positioning System

${ }^{6}$ Procedural
}

سازمانهاى برنامهريزى منطقهاى سالها است كه به بررسى سفرهاى روزانه با هدف بلهدست آوردن

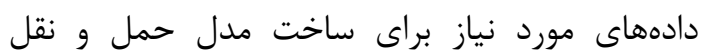

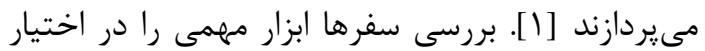
متخصصان حمل و نقل براى برنامهريزى، طراحى،

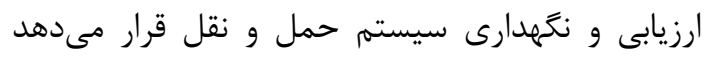

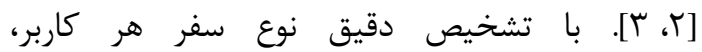

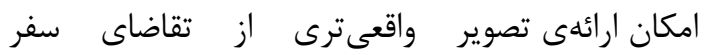
فراهم مىشود [l].

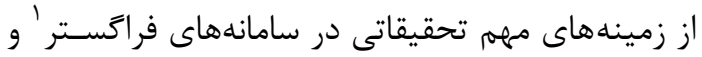

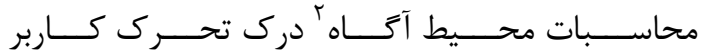

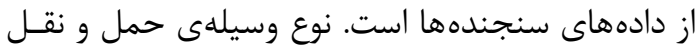

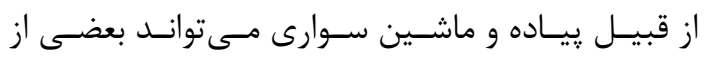
مشخصههاى محيط كـاربر متحــرك را تعيـين نمايـد و

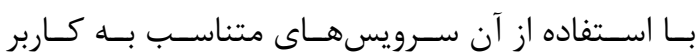

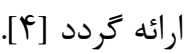
ييـادهسـازى فنـاورىهـاى تعيـين موقعيـت دقيـق در تلفنهاى همراه منجر به ايجاد برنامهاى كاربردى شده

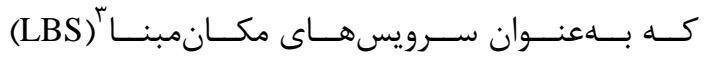
شناخته مى شوند. در اين سرويسها از مكان دسـتَاه و

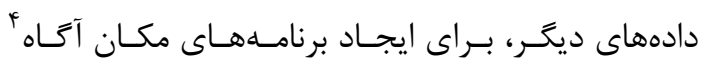

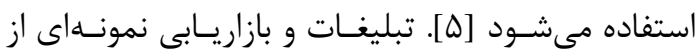

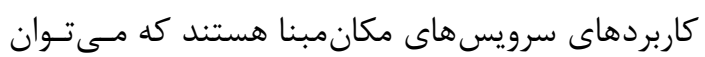
به آن اشاره نمود. بنابراين با دانستن نوع وسيلهى سـفر مىتوان تبليغات هدفمند و سفارشى را به تلفـن همــراه

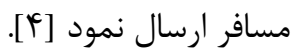

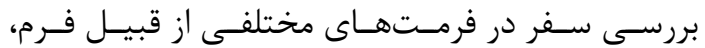

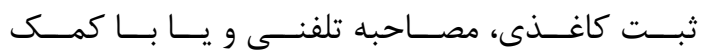

\footnotetext{
${ }^{1}$ Ubiquitous

${ }^{2}$ Context aware

${ }^{3}$ Location Based services

${ }^{4}$ Location aware
} 


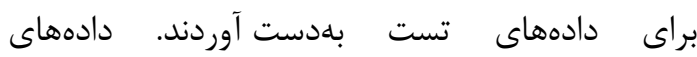

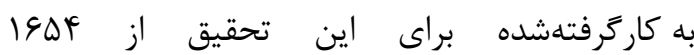
قطعه تشكيل شده است. اين تحقيق نشان داد كه آندائ

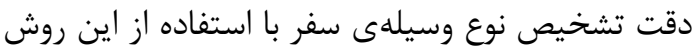

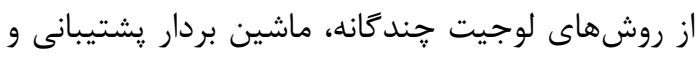
شبكهى عصبى بيشتر است [Q1 []. متأسفانه دانشى كه

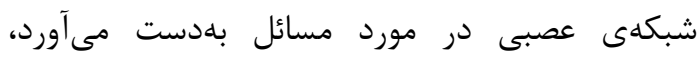

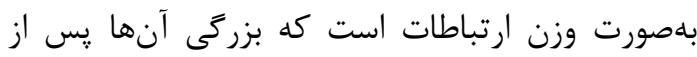

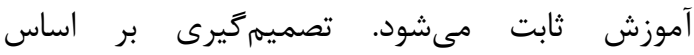
جعبهى سياه كه دانش آن قابل تفسير نمودن نيست در خيلى از امور امكانيذير نيست. در اين تحقيقائ تفيقات ندان

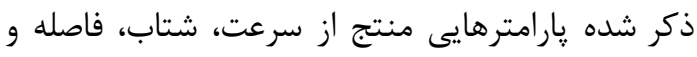
كيفيت دادهها براى تشخيص نوع وسيلهى سفر مورد استفاده قرار كرفته است.

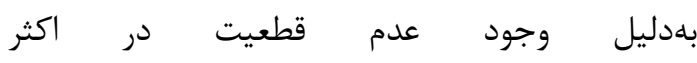

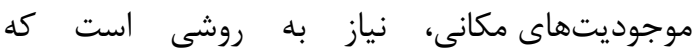

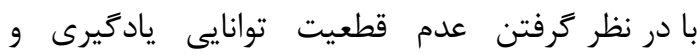

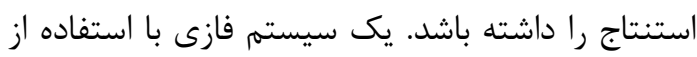

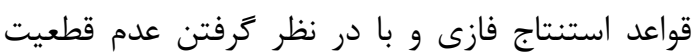
قادر به ارائهى تصميم گيرى و ياسخ مى باشد. تعيين فرم مناسب اين قواعد مىتواند به سيستم توانايى لازم براى

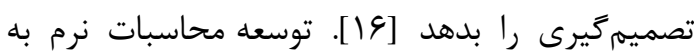
تلفيق روشهاى هوش مصنوعى از قبيل شبكهى عصبى و سيستم استنتاج فازى كمك كرده است. منطق فازى

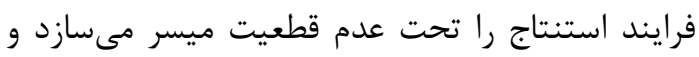
شبكدى عصبى نيز قابليتهايى از قبيل يادَّيرى،

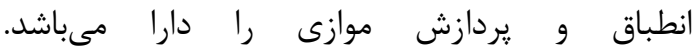
سيستم تركيبى شبكه فازى عصبى ناميده مى شود [V]

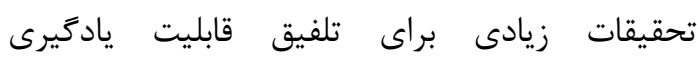

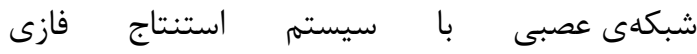
بهمنظور استخراج قوانين اوليهى سيستم فازى و و

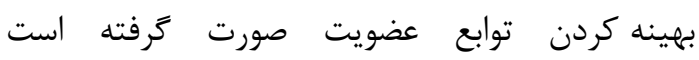
$[19.11 .1 \mathrm{~V}]$

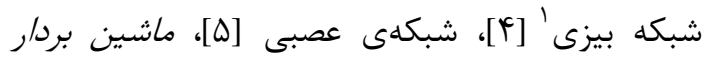

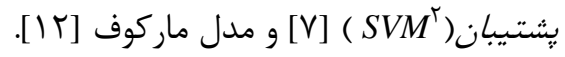
الكوريتمهاى يادگيرى ماشين را مىتوان به سه مرحله تقسيمبندى نمود: جمعآورى دادهها، انتخاب متغيرها

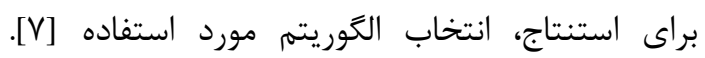

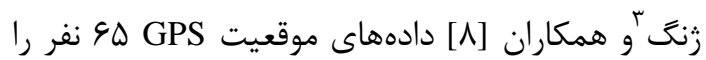
براى ·ل ماه جمعآورى نمودند و با بهكاركيرى

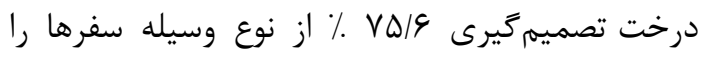

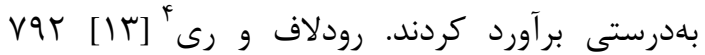
خط سير را به دادهاى تست و آموزش تقسيم نمودند

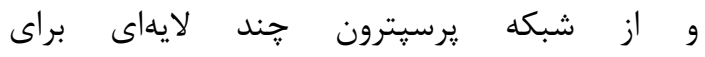
تعيين نوع وسيلهى سفر استفاده بردند. نتايج ايشان

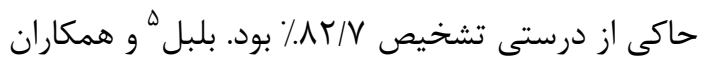

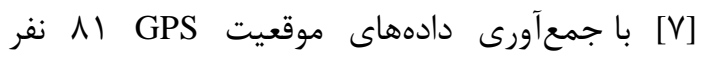

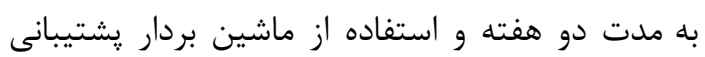
دقت M ـ ٪ براى شناسايى نوع سفر را بهدست آوردند.

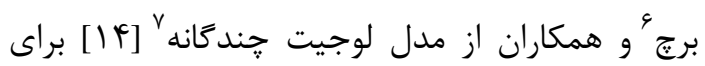

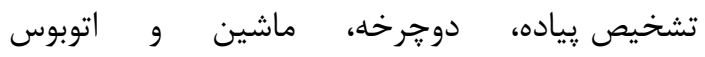
استفاده نمودند. دادههاى مورد استفاده، متشكل از 9 و 9 و

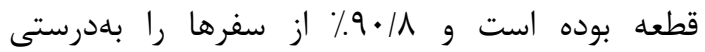

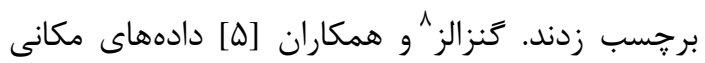

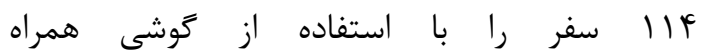

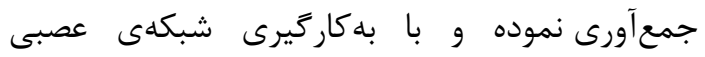

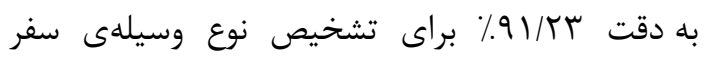

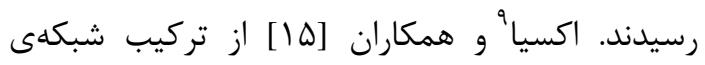

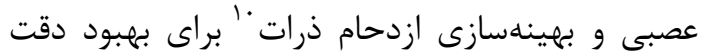

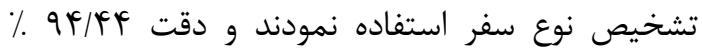

${ }^{1}$ Bayesian network

${ }^{2}$ Support Vector Machine

${ }^{3}$ Zheng

${ }_{5}^{4}$ Rudloff and Ray

${ }^{5}$ Bolbol

${ }^{6}$ Broach

${ }^{7}$ Multinomial logit

${ }^{8}$ Gonzalez

${ }^{9}$ Xiao

${ }^{10}$ Particle Swarm Optimization (PSO) 
آستانهى كمترين سرعت براى پالايش دادههـايى اسـت

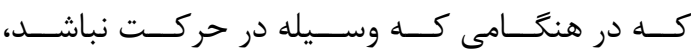

$$
\text { توليد مىشود [r] [r]. }
$$

الكوريتم نقاط بحرانى متفاوت از فاصلهى بروز رسانى

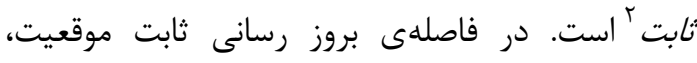
هر X ثانيه بدون در نظر گرفتن اينكه اطلاعات موقعيت

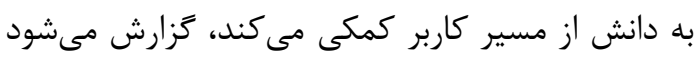

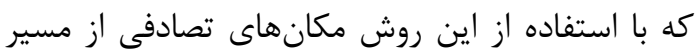

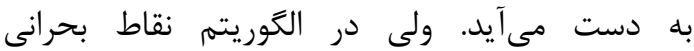

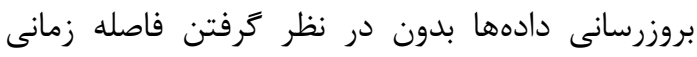

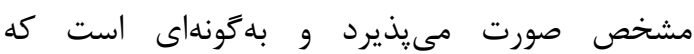
مكانهاى مهم مسير را فراهم مى آورد. اين الكوريتم

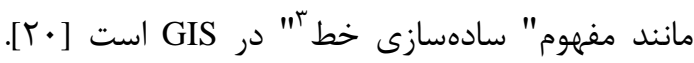

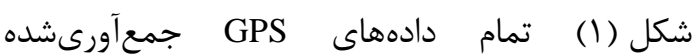
در طول سفر با ماشين و شكل (r) دادههاى GPS

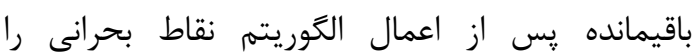
نمايش مى دهند.

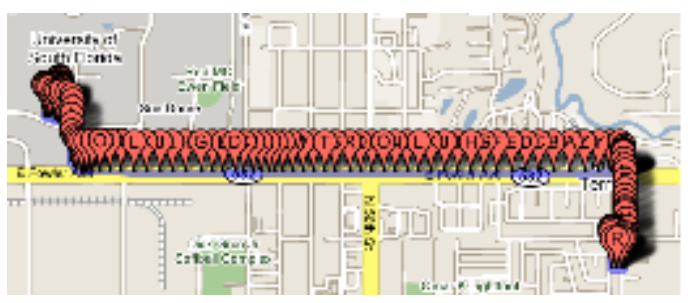

شكل I : تمام نقاط GPS در مسير سفر [ه]

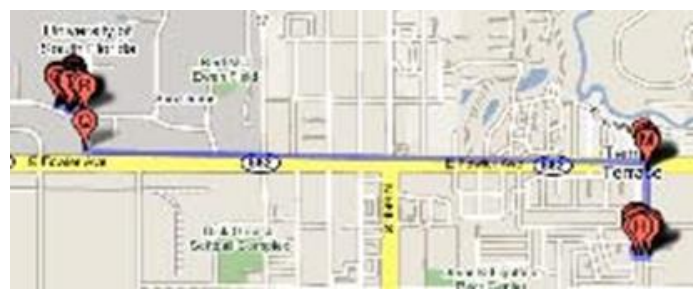

شكل r] : نقاط بحرانى در مسير سفر [ه]

\footnotetext{
${ }^{2}$ Fixed update interval

${ }^{3}$ Line simplification
}

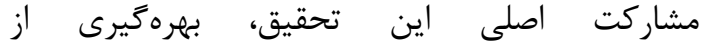

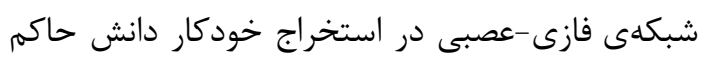
بر محيط در قالب قوانين فازى براى پيشبينى نوع وسيلهى سفر است. استخراج خودكار ريايخاه دانش فازى اين توانايى را به سيستم مىدهد كه بدون

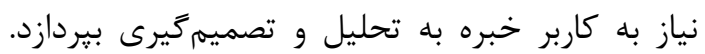
شايان ذكر است كه ييش از اين، از شبكه عصبى - فازى براى شناسايى نوع وسيلهى سفر و و استخراج قوانين فازى استفاده نگرديده است. براى اين منظور در دو مدل قوانين استخراج گررديد. در مدل مدل اول براى شناسايى نوع وسيلهى سفر، كل دادههاى جمع آورى شده و در مدل ديخر دادههاى GPS كمترى كه با استفاده از الگوريتم نقاط بحرانى استخراج شدهاند،

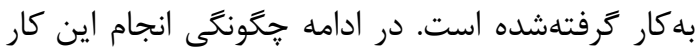
شرح دادهده است. r- مواد و روش بررسى در اين بخش ابتدا با توضيح كوتاهى در مورد

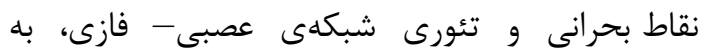
بيان مراحل اجرا و :ييادهازى مدل توسعه دادهشه

$$
\text { يرداخته مىشود. }
$$

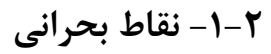

الخوريتم نقاط بحرانى ' بهمنظور كاهش حجم دادههـاى

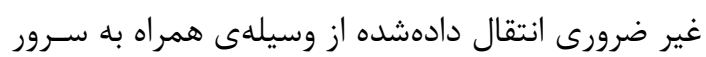

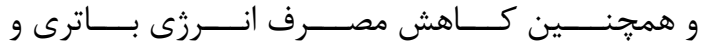
هزينههاى مالى توسعه دادهشده است. با استفاده از اين

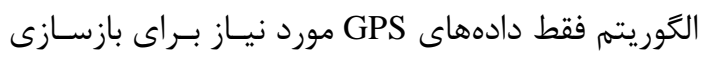

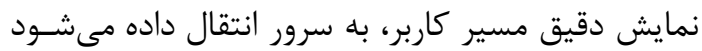
[·r]. بر اساس اين الكوريتم، نقـاط اول و آخــر سـفر و همجنين هر نقطهاى كه تغيير جهـت قابـل تـوجهى از نقطهى بحرانى قبلى داشته باشد و همجنين سرعت هُ آن

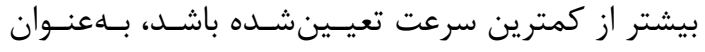

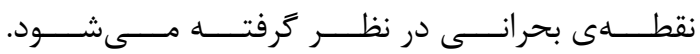

${ }^{1}$ Critical point 
لايه ه : هر كره در اين لايه كره ثابت است و وظيفهى جمعبندى تمام خروجى قوانين را دارد. روشهاى مختلفى براى تغيير و بهينهسازى يارامترهاى

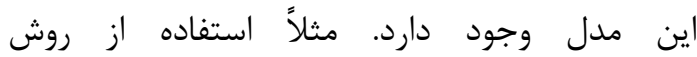

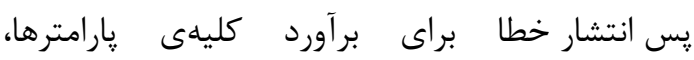

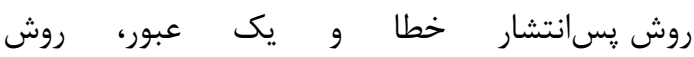
كمترين مربعات براى تخمين اوليه پارامترهاى نتيجه،

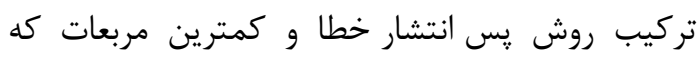

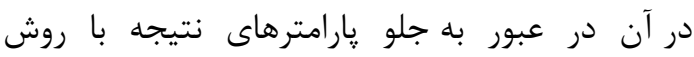
كمترين مربعات و در عبور به عقب از پس إنتشار خطا

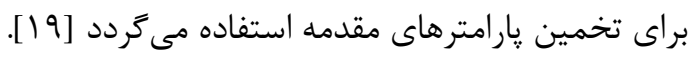
با توجه به توضيحات دادهده، بهطوركلى ساختار عمومى سيستم استنتاج عصبى-فازى تطبيقى

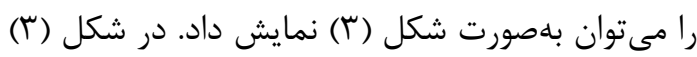
اين ساختار براى سه متغير ورودى و براى هر متغير، سه تابع عضويت رسم شده است. همانطور كه بيان شد، در سيستم استنتاج عصبى-فازى تطبيقى، قانونها و توابع عضويت اوليه بايد مشخص باشد و اين سيستم فقط يارامترهاى توابع عضويت را بهينه مى كند. براى تعيين قانونها و واند

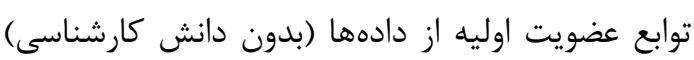
روشهاى متفاوتى وجود دارد كه در اين تحقيق از روش خوشهبندى كاهشى، و تقسيمبندى كريدى

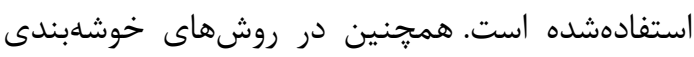

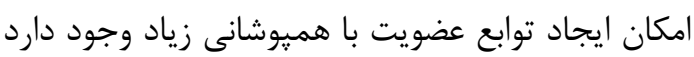
كه با استفاده از روش كاهش تعداد توابع عضويت براى إي هر متغير، تفسيريذيرى قوانين بهبود يافت. در ادامه هر يك از موارد فوق بهاختصار تشريح مى تفود.
Y-Y - تئورى شبكهى عصبى - فازى

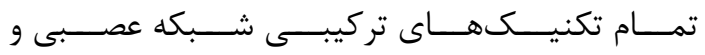
سيستم هاى فازى، شبكه عصبى فازى ناميده مسى شـود.

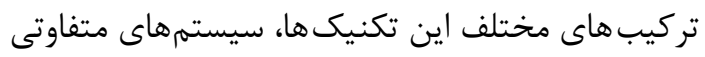
از قبيل سيستمهاى عصبى فازى مشاركتى، همز زمـان و

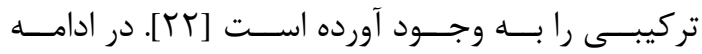

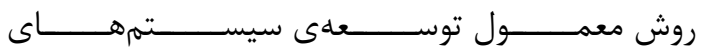
عصبى فازى تركيبى كه در اين تحقيق مـورد اسـتفاده

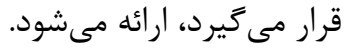

سيستم استنتاج عصبى-فازى تطبيقى ( 'ANFIS'):

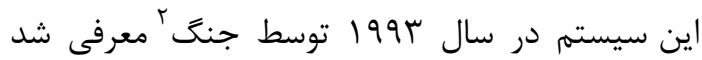
كه براى اجراى سيستم فازى سوَنو در ساختار شبكه

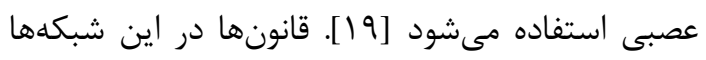
بايد مشخص باشند و تنها توابع عضويت مقدم و مؤخر قانون را مشخص مى كنند. اين مدل داراى ها لايه است

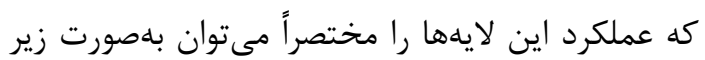

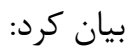
لايه 1 : توابع عضويت متغيرهاى ورودى كه بهعنوان تابع گره است را شامل مىشود. لايه r : هر كره در اين لايه به كرههايى كه نمايش دهندهى يیش فرضهاى قانون موردنظر است

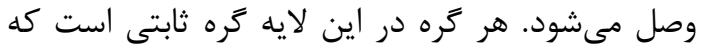

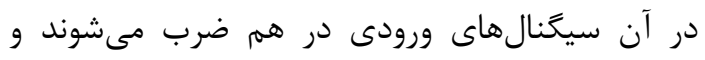
وزن يك قانون را بيرون مىفرستد. لايه ץ : هر گره در اين لايه عمل محاسبهى وزن نسبى

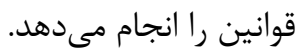
لايه |F : هر كره در اين لايه داراى تابع گره مىباشد كه به تمام ورودىها و يك گره در لايهى سوم متصل است.

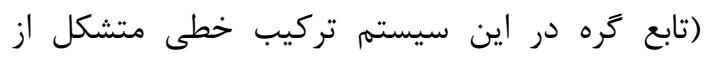

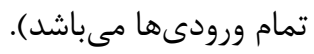

${ }^{1}$ Adaptive Neuro - Fuzzy Inference System ${ }^{2}$ Jang 


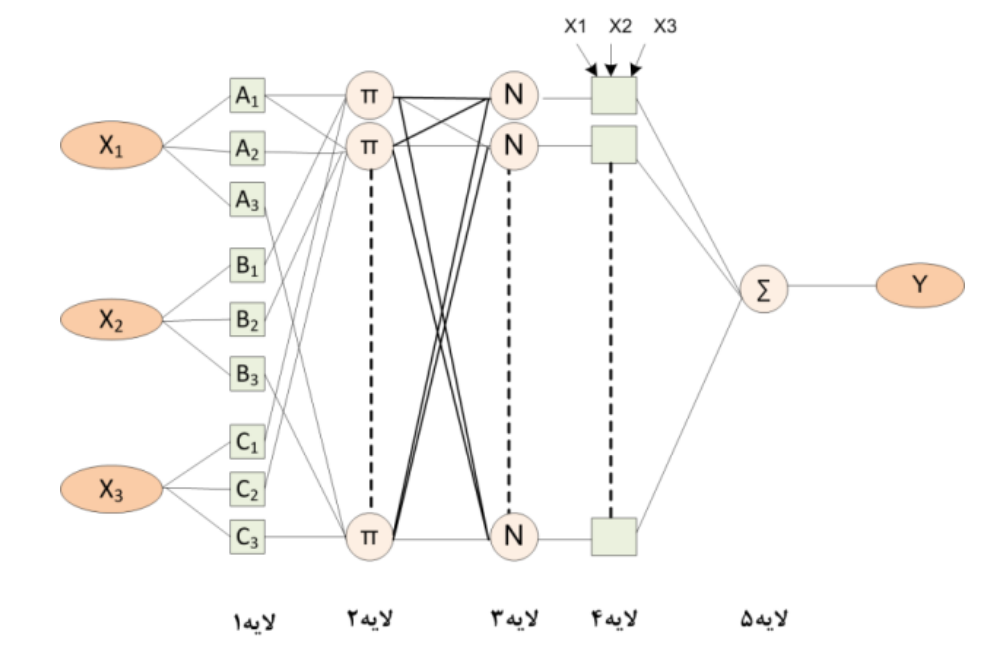

\section{شكل ץ : ساختار كلى سيستم استنتاج عصبى -فازى تطبيقى}

\section{Y-Y - روش تقسيمبندى تريدى}

روش تقسيمبندى گريدى داراى ساختار كريدى

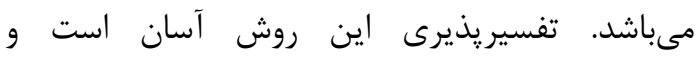

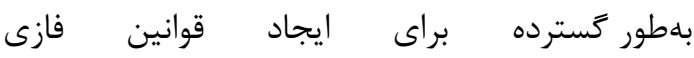
استفاده مىشود. اين روش براى تقسيمبندى فضاى بردين ورودى مورد استفاده قرار مى كيرد و در سيستم فازى إنى

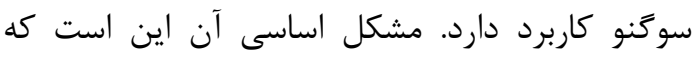

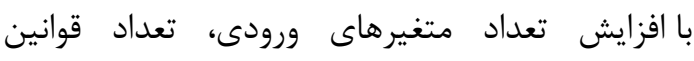
بهصورت نمايى افزايش مى يابد. براى هر قانون تعدادى

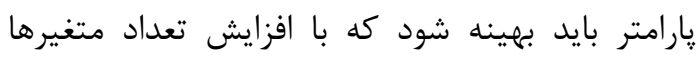

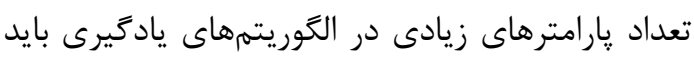

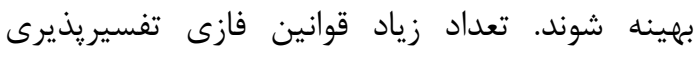

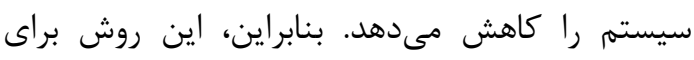

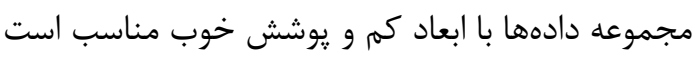

[rQ]

r-ها - كاهش تعداد توابع عضويت براى هر متغيــر

\section{و سادهسازى قوانين}

در روشهاى خوشهبندى، امكان ايجـاد توابـع عضـويت

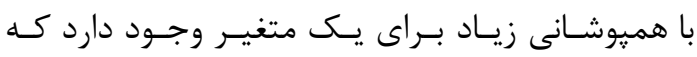

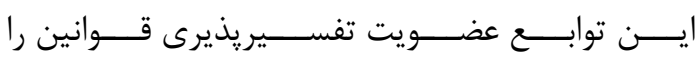

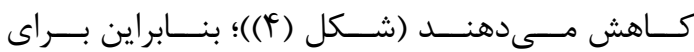

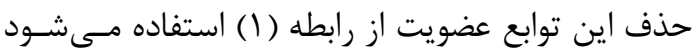
[rV,rG]

\section{r-r- روش خوشهبندى كاهشى'}

خوشهبندى كاهشى يكى از روشهاى معمول

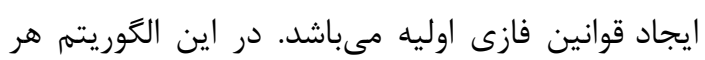

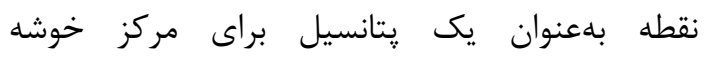

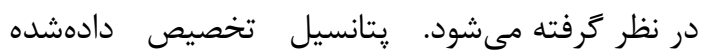

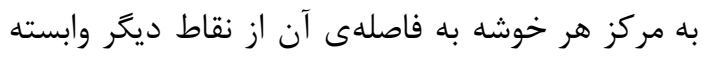

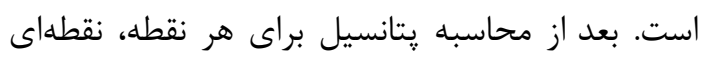

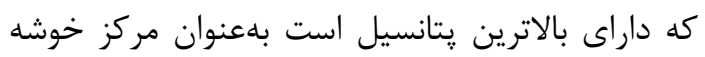

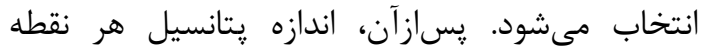

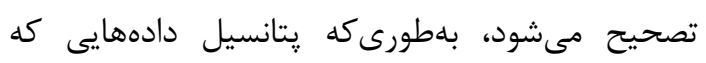

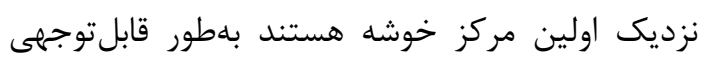

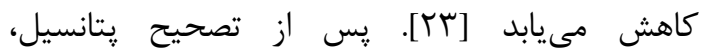

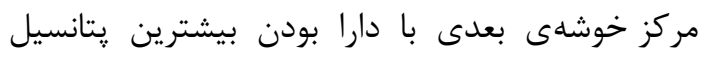

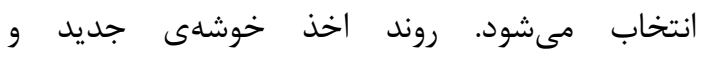

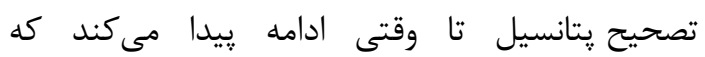

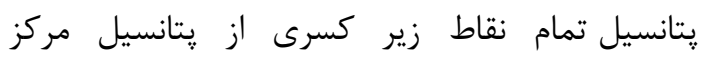

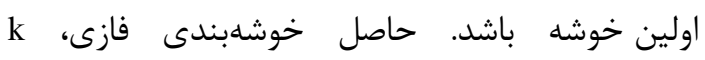

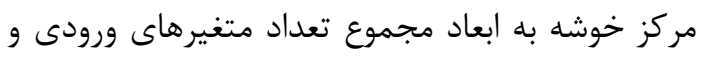

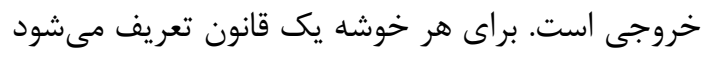

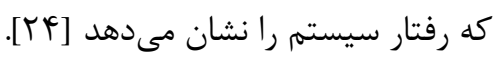

${ }^{1}$ Subtractive clustering 
براى تبديل طبقهبندى خند كلاسى بــه مجموعـهاى از

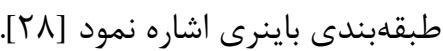
با توجه به اينكه شبكهى فازى-عصبى ايجادشده داراى يك خروجى است مى توان مسئله را به جند إند مسئلهى

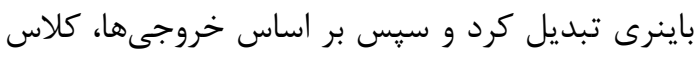

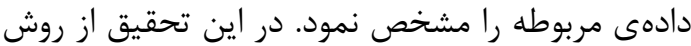

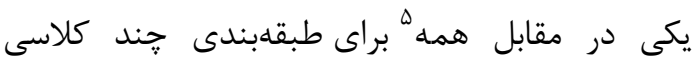
استفادهده است. اين روش سادهترين روش تبديل مسئلهى طبقهبندى ميان k كلاس به k مسئلهى باينرى است بلهورى كه هر مسئله يك كلاس مشخص

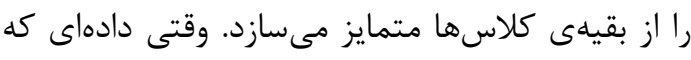
كلاس آن معلوم نيست وارد فرآيند كلاسهبندى شود، برجسب آن مربوط به كلاسى مىشود كه بيشينه خروجى را دارا باشد.

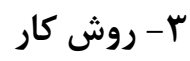

در اين تحقيق از شبكهى عصبى -فازى بـراى اسـتخراج

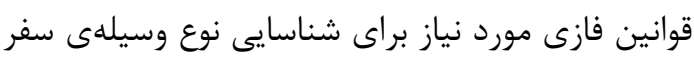

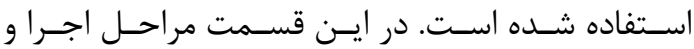

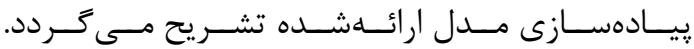

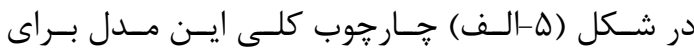

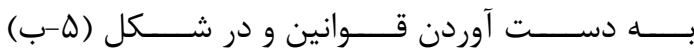
جكَونكى شناسايى نوع وسـيله سـفر آورده شـده اسـت.

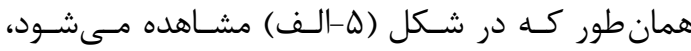

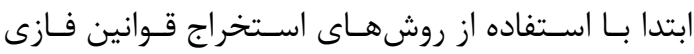

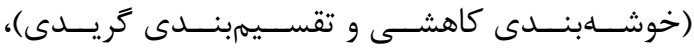

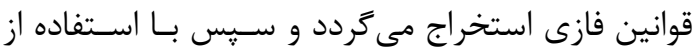

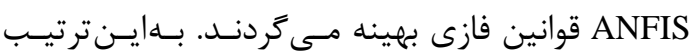

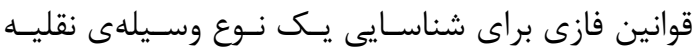
تعيين مى كردد. يس از تكــرار ايـن روش قـوانين فـازى براى شناسايى هر نـوع وسـيله نقليـهـ ايجـاد مسىشـود.

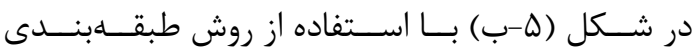
جند كلاسى نـوع وسـيلهى سـفر مشـخص مسى كـردد.

\footnotetext{
${ }^{5}$ One-Versus-All (OVA)
}

$$
S\left(A_{i j}, A_{k j}\right)=\frac{\sum_{l=1}^{L} \min \left\{u_{i j}\left(x_{j l}\right), u_{k j}\left(x_{j l}\right)\right\}}{\sum_{l=1}^{L} \max \left\{u_{i j}\left(x_{j l}\right), u_{k j}\left(x_{j l}\right)\right\}} \text { (1) }
$$

در اين رابطه ز نشاندهندهى هر متغير، i و نشاندهنده تابع عضويت آن متغير، آن آنمايانكر

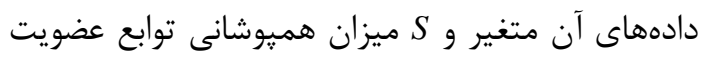

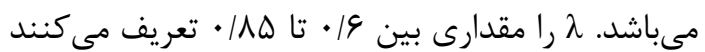

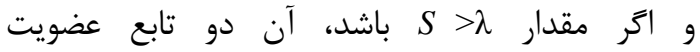
داراى هميوشانى زيادى هستند و تابع عضويت جديدى

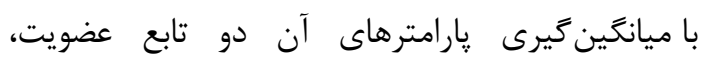
جايخزين آن دو مجموعهى فازى مىشود. بدين ترتيب بدون اينكه دقت تغيير محسوسى كند، تفسيريذيرى قانون افزايش مى يابد [TV].

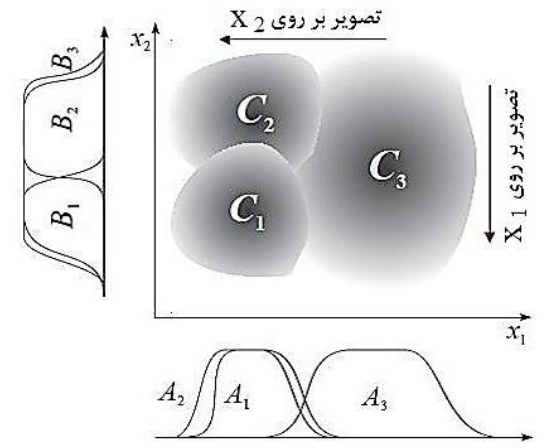

شكل F : توابع عضويت اضافى كه بهوسيلهى خوشهبندى به وجود مى آيد [Y)]

r-9- روشهاى طبقهبندى جند كلاسى'

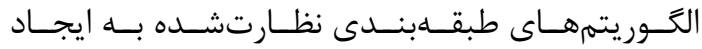

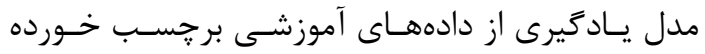

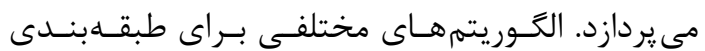
קند كلاسى يِيشنهاد شده كه از ميان آنهاى مى تـوان

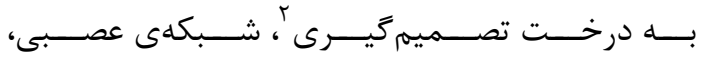

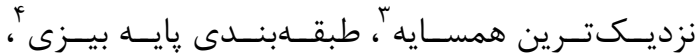

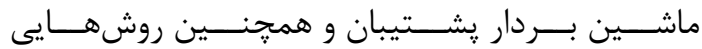

${ }^{1}$ Multiclass Classification

${ }^{2}$ Decision Trees

${ }^{3}$ K-Nearest Neighbor

${ }^{4}$ Naive Bayes Classifiers 
كلاسى كه بيشترين مقدار تعلق را دارد، نـوع وسـيلهى سفر ورودى را تعيين مى كند.

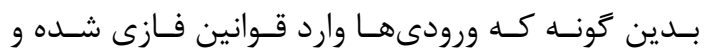
ميزان تعلق به هــر كـلاس بـه دسـت مـى آيـد. سـيس

روش هاى استخراج

قوانين اوليه فازى اليخراج

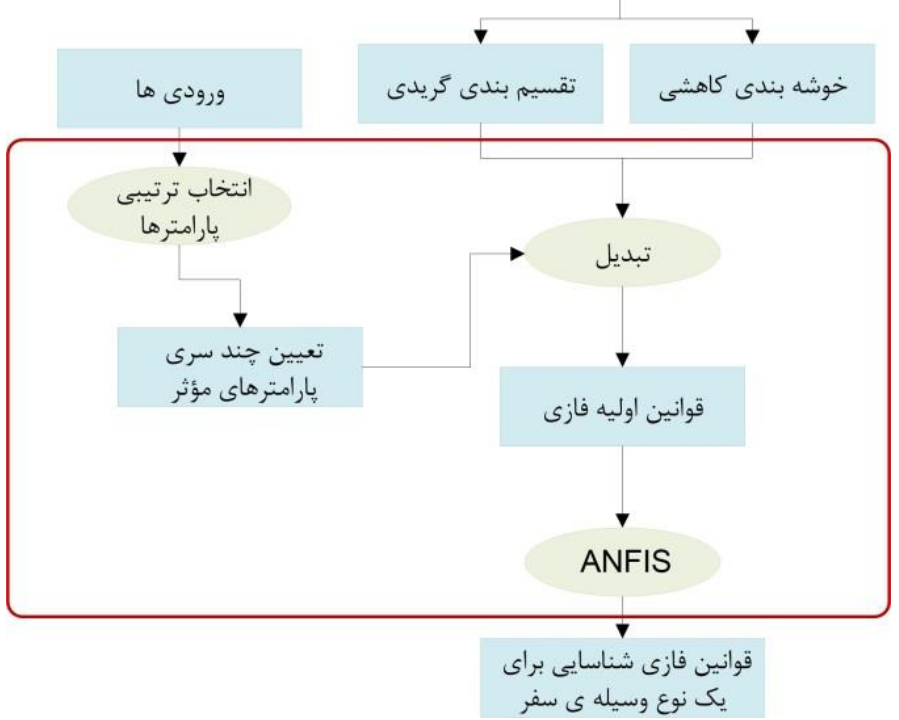

(الف)

ورودى ها

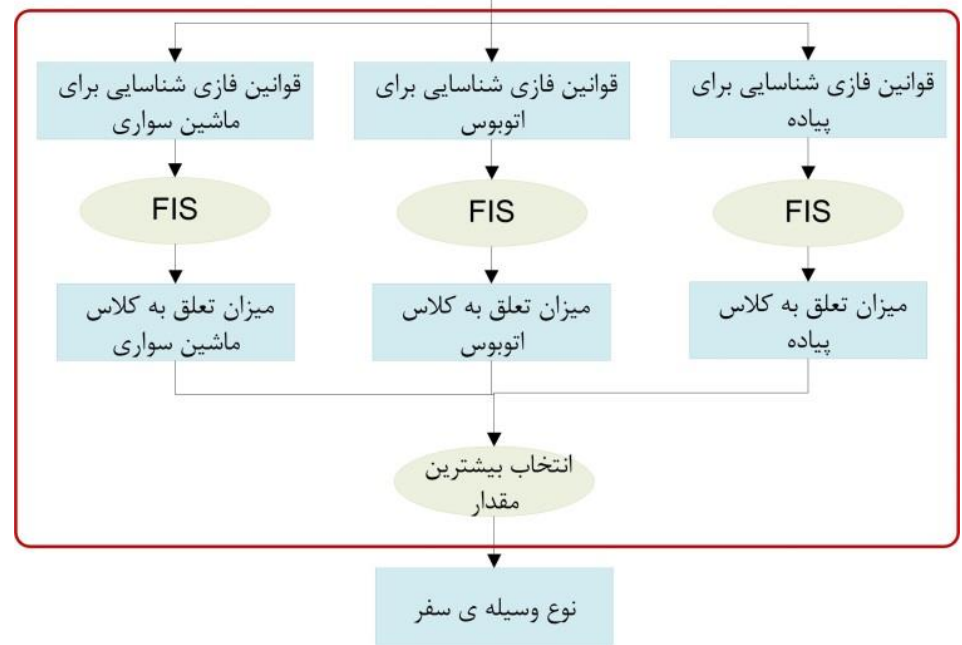

(ب)

شكل ه : مدل مفهومى تحقيق

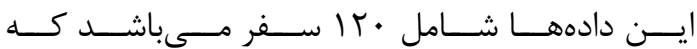

r-1 اخذ و آمادهسازى داده

دادههـاى مــورد اسـتفاده در ايــن تحقيـق از دانشـكده

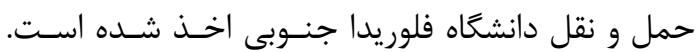


دقت افقى، انحراف معيار فاصلهها بين مكانهاى توقف و ميانگين زمان توقف مى بحاشد [ه]. متوسط و بيشينه سرعت بهعلـت اينكـهـ در حالـتهــاى

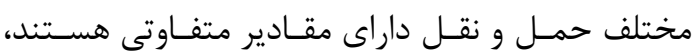

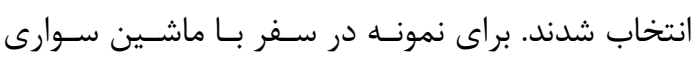

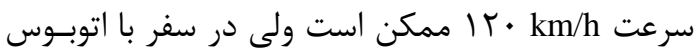

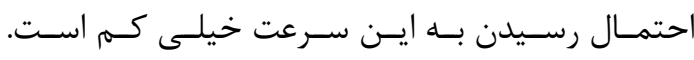

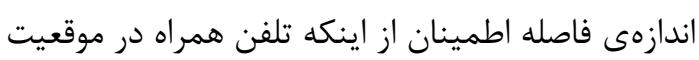

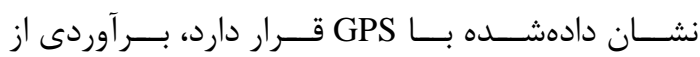

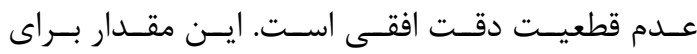

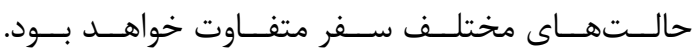

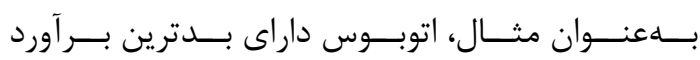

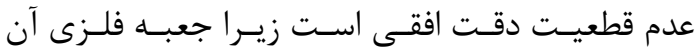

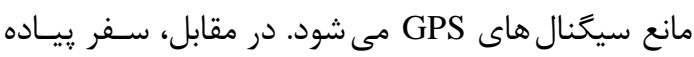

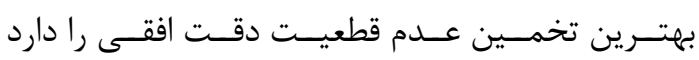

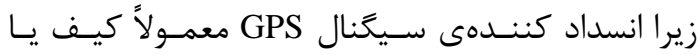

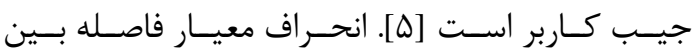

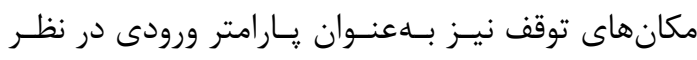

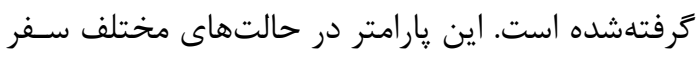
متفاوت است. براى مثال سفر با اتوبوس احتمـالاً داراى فاصلهى كمترى بين مكانهاى توقف نسبت به ماشـين

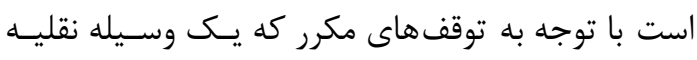

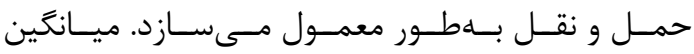

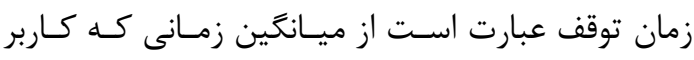

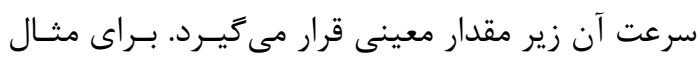

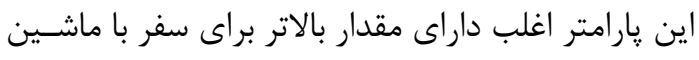

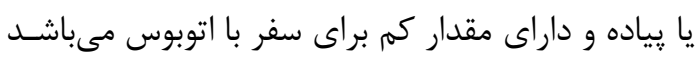
زيرا در اتوبوس توقف كوتاه صورت مى خيرد تا مسـافران

سوار يا يياده شوند [ه].

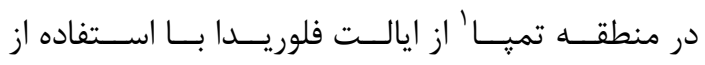

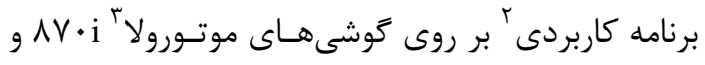

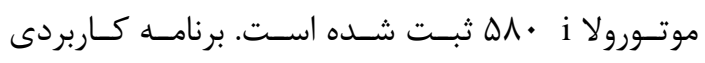

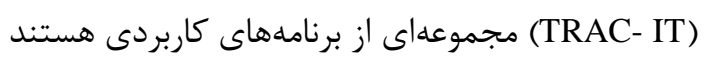

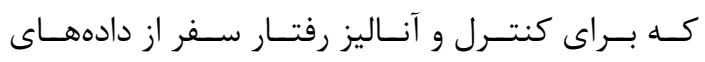

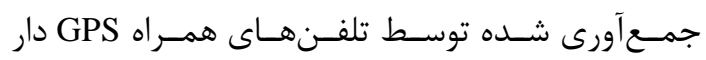

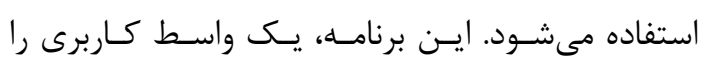

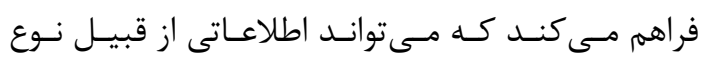

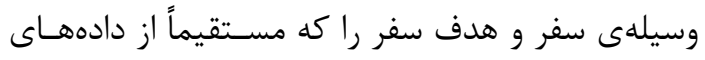

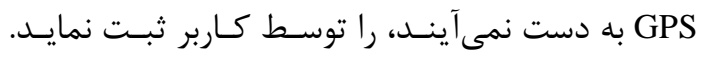

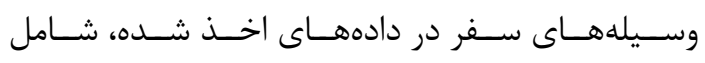

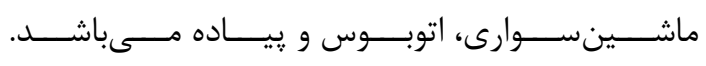

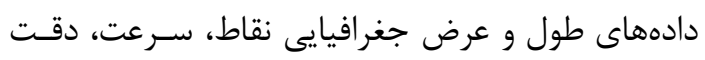

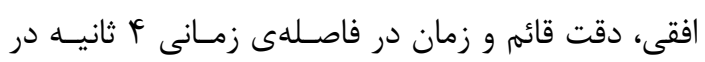

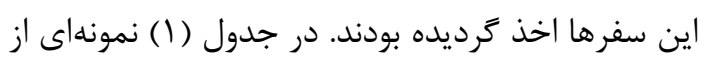

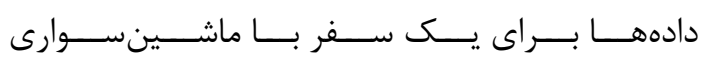
نمايش دادهده است.

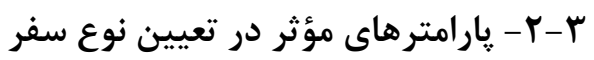
در ادامه به معرفى يارامترهاى موثر در تعيين نوع سـفر لِّر

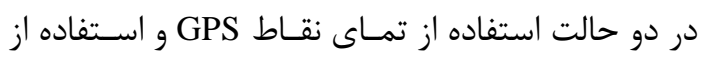
نقاط بحرانى يرداخته مىشود. r-r-1- در حالت شناسايى نوع وسـيلهى ســفر GPS با استفاده از كل نقاط الت سناط مشخصههايى از دادههاى GPS كه تفاوت بارزى بين

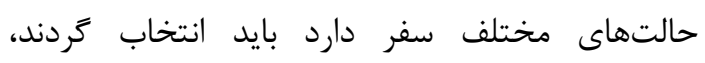

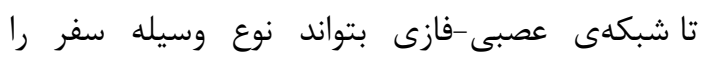

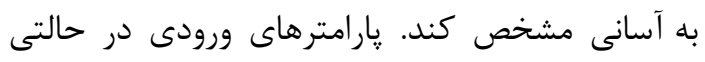

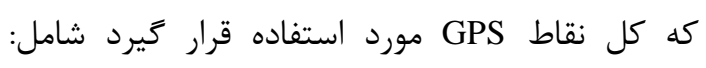

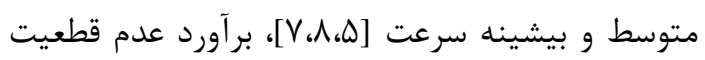

\footnotetext{
${ }^{1}$ Tampa

${ }^{2}$ Java ME application TRAC-IT

${ }^{3}$ Motorola
} 
جدول ا : نمونهاى از دادههاى جمع آورى شده

\begin{tabular}{|c|c|c|c|c|c|c|}
\hline زمان & قدائم (دسى قطعيت دقتر) & عدم قطعيت دقت & 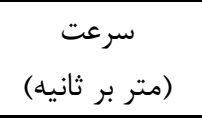 & عرض جغرافيايى & $\begin{array}{c}\text { طول جغرافيايى } \\
\text { (درجه) }\end{array}$ & شناسه \\
\hline$|\varphi: f|: \Delta \mid$ & $F V / \cdot \Lambda \Lambda \cdots \mid r \Delta$ & Tr/DT/9৭१४G & ז. שسחسس & $-\Lambda r / 4 \cdot G \mid r V q r$ & $r \mathrm{~N} / q \cdot \cdots \cdot r \cdot q$ & سזטג \\
\hline$|q: f|: \Delta \varphi$ & $\Delta I / V \Delta$ & $r V / q \vee f \ldots q r$ & If/ffffffes & $-\Lambda T / F \cdot \Delta V T r \Delta V$ & $r N / \cdot q \cdot r g r F G$ & سHטا \\
\hline
\end{tabular}

قابل محاسبه مىباشد. بيشينه شتاب متوسط را مىتوان از مجموعلى شتاب متوسط انتخاب نمود [ه]. همجنين شتاب متوسط نهايى از تقسيم مجموع شتاب متوسط مجطي بر تعداد بهدست مى آيد.

سرعت متوسط بين هر دو نقطهى بحرانى با اسـتفاده از

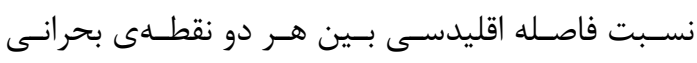

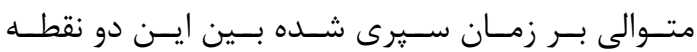

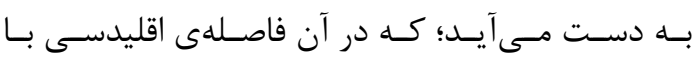
به كاركيرى مختصات اين دو نقطه محاسـبه مسى گـردد.

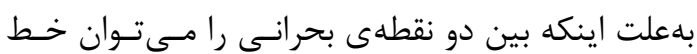

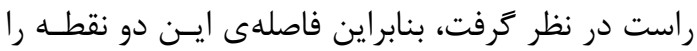

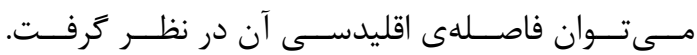

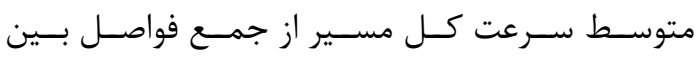

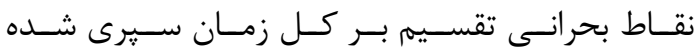

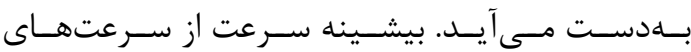

بلهدستآمده در نقاط بحرانى انتخاب مىشود [ه]. انحراف معيار سرعت بين نقاط بحرانى با استفاده از

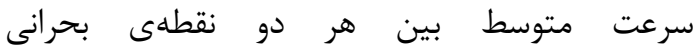

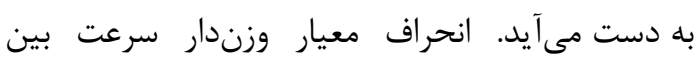

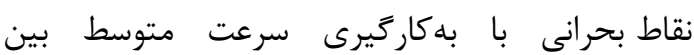
هر دو نقطهى بحرانى و در نظر گرفتن فاصلهى بين نقاط بحرانى بهعنوان وزن آنها محاسبه ميى درد درد. در شكل (9) به ترتيب تفاوت نسبت تعداد نقاط بحرانى در سفر به كل فاصلهى سفر، نسبت تعداد نقاط بحرانى در سفر به كل زمان سفر، انحراف معيار سرعت متوسط به

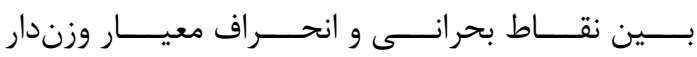

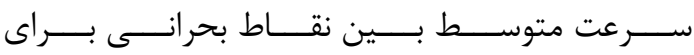

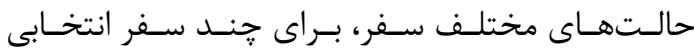
نمايش دادهشده است. همانطور كه مشاهده مىشود با مئن
r-Y-r-r- در حالت شناسايى نوع وسيلهى سفر با استفاده از نقاط بحرانى

شناسايى نوع وسيلهى سفر با استفاده از نقاط بحرانى از مزاياى فراوانى برخوردار است؛ زيرا تنها مشخصات اين نقاط به سرور انتقال داده مىشوند. بنابراين بيشتر يارامترهاى ورودى ذكر شده براى حالت قبل در اينجا كارا نمىباشد. براى مثال براى تعيين انحراف معيار فاصلهها بين مكانهاى توقف و ميانگين زمان توقف، كل دادههاى GPS مورد نياز مىباشد كه در اين حالت در دسترس نيست. به اين دليل ورودىهاى شبكهى فازى-عصبى متفاوت از حالت قبل مىباشد. ورودىها در اين حالت عبارتاند از: بيشينه و متوسط شتاب،

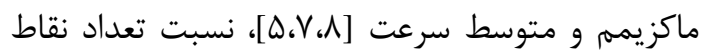
بحرانى در سفر به كل فاصلهى سفر، نسبت تعداد نقاط بحرانى در سفر به كل زمان سفر، كل فاصلهى سفر و فاصلهى متوسط بين نقاط بحرانى [ه]، انحراف معيار سرعت بين نقاط بحرانى و انحراف معيار وزندار سرعت بحتئ بين نقاط بحرانى. محاسبهى متوسط شتاب وقتى كه از الكوريتم نقاط بحرانى معمولى استفاده مئى مشود باب مشكل

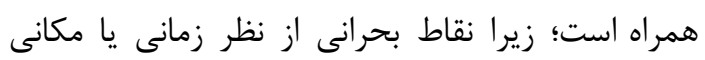

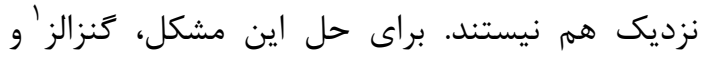

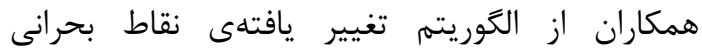

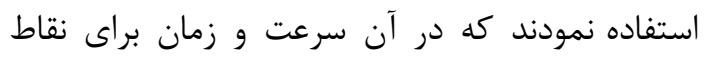
GPS ثبت مىشود. با داشتن دو زمان و سرعت در هر

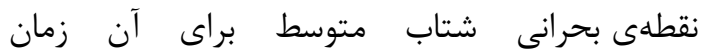

${ }^{1}$ Gonzalez 
ماشــين و اتوبــوس تفكيــك نمــود. شـــكل (9-ج)

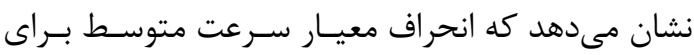

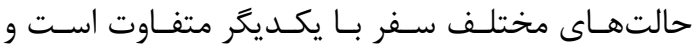

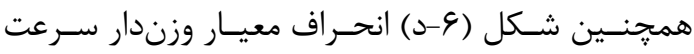

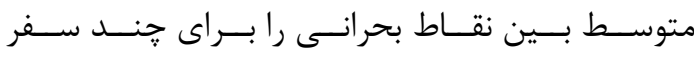
نمايش مى دهد كه بيشتر بودن مقدار آن براى ماشـين،

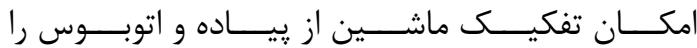

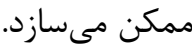

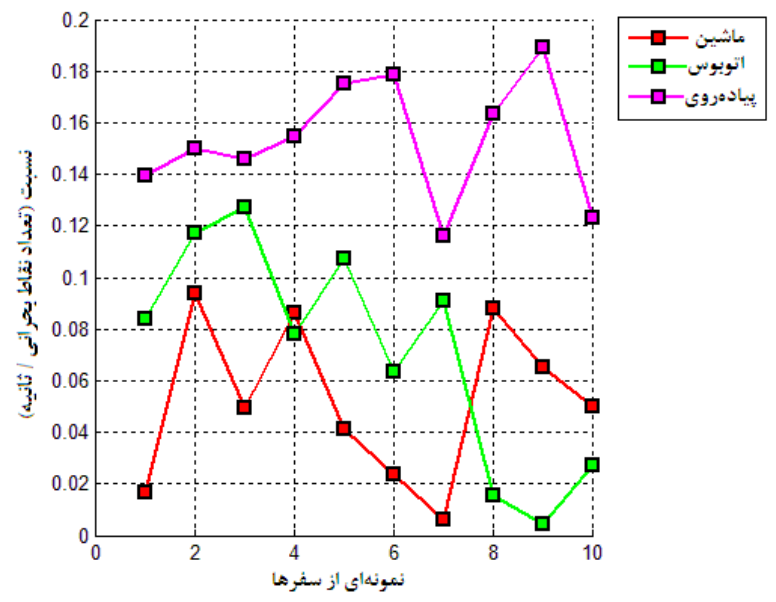

ب: نسبت تعداد نقاط بحرانى به زمان سفر براى جند سفر

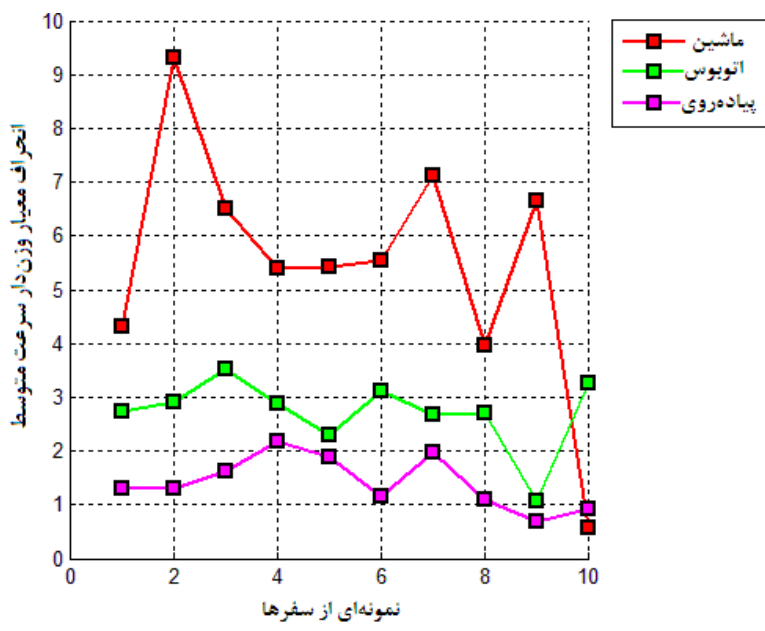

د : انحراف معيار وزندار سرعت متوسط بين نقاط بحرانى براى جند سفر
انتخــاب ايــن يــارامترهـــا امكــان تفكيـــ نــوع ســفر

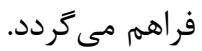

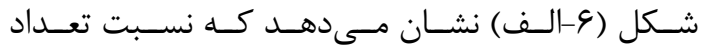

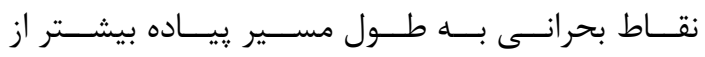

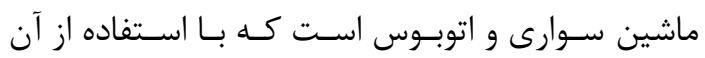

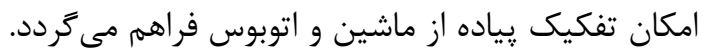
در شكل (و-ب) نيز مشاهده مىشود كه نسـبت تعـداد

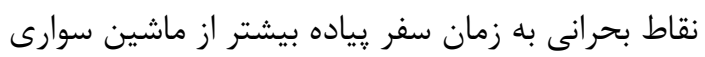

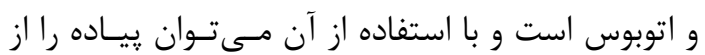

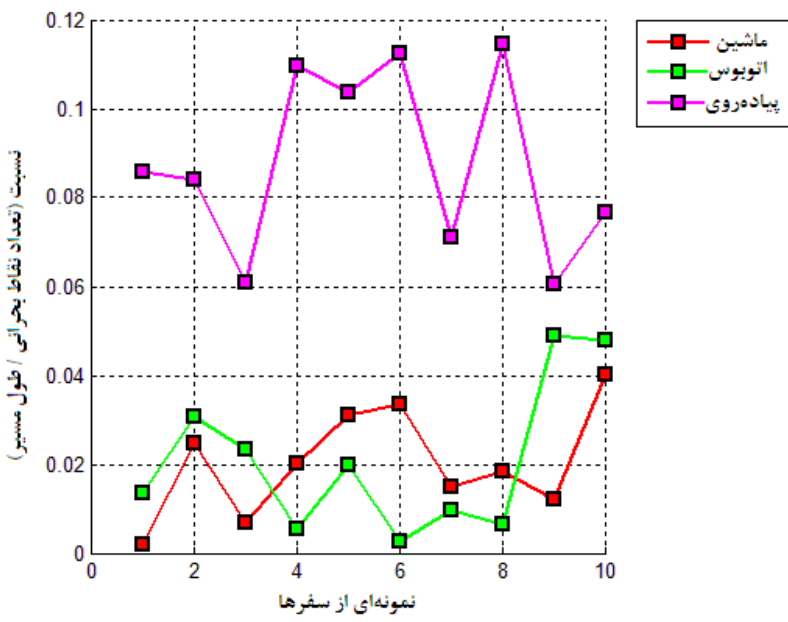

الف : نسبت تعداد نقاط بحرانى به طول مسير براى خند سفر

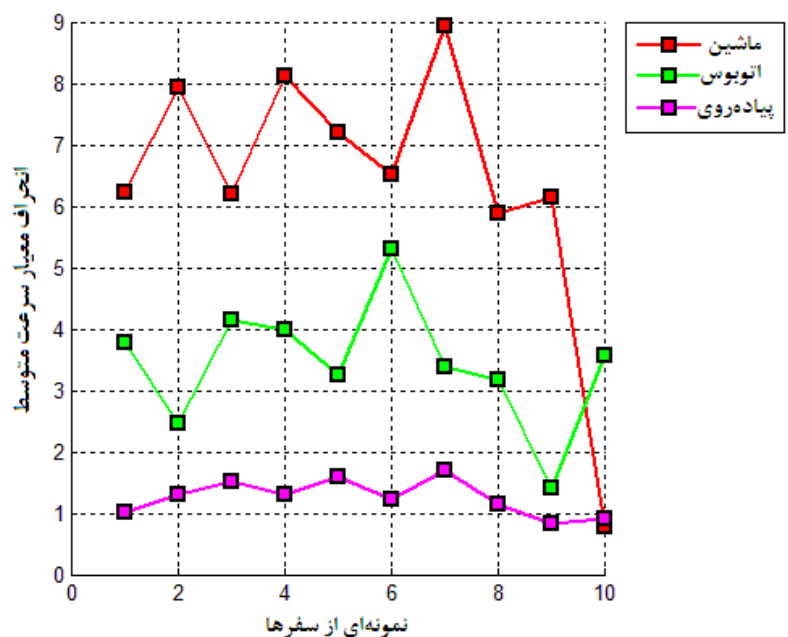

ج : انحراف معيار سرعت متوسط بين نقاط بحرانى براى جند سفر رسفر شكل 9 : نمودارهاى جند پارامتر استخراجشده از دادهها براى جند سفر 


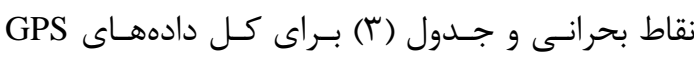

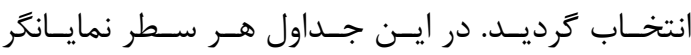

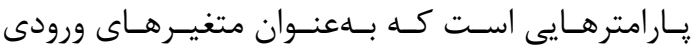
به شبكهى عصبى -فازى مورد استفاده قـرار مسى

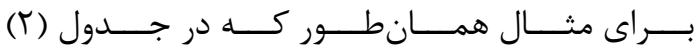

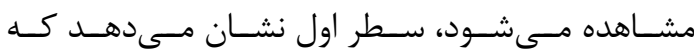

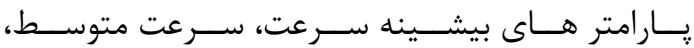

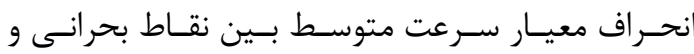

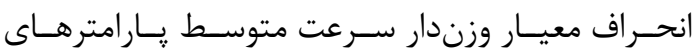

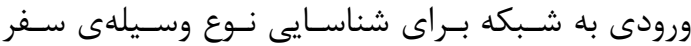
در حالت استفاده از نقاط بحرانى مىباشند.

r-F- آموزش و تست شبكهى ANFIS

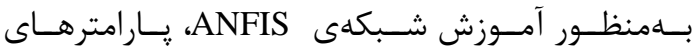

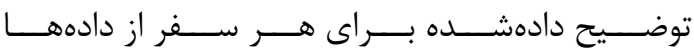

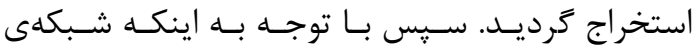
ANFIS

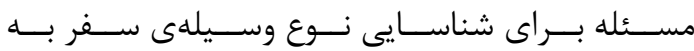

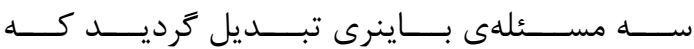

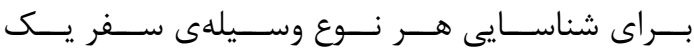

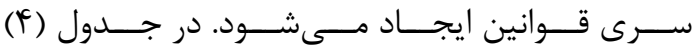

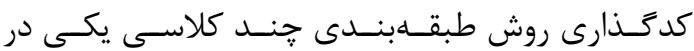

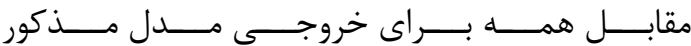
نمايش دادهشه است. بهعنوان نمونه اخر دادهاى مربوط هري

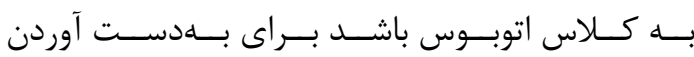

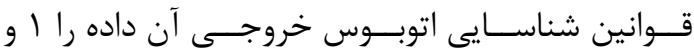

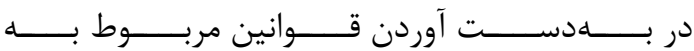

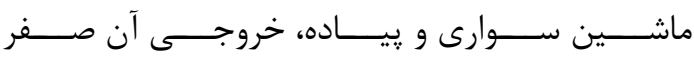

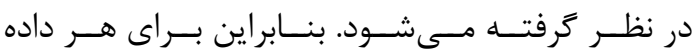
سه خروجى در نظر گرفته شد.

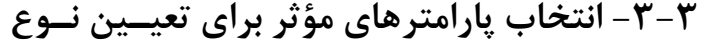
وسيلهى سفر

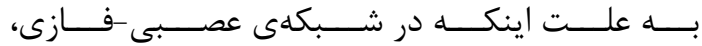

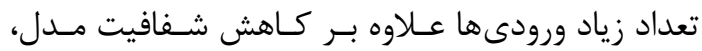

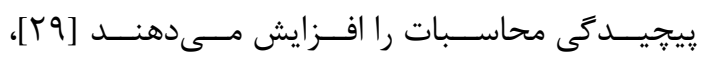

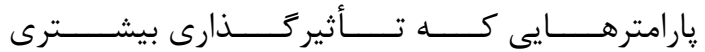

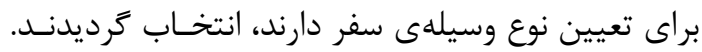

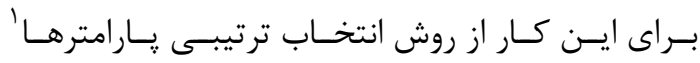

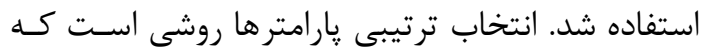

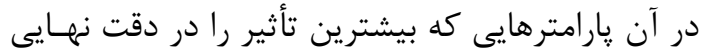

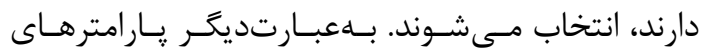

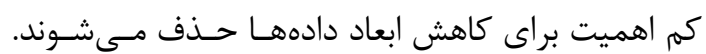

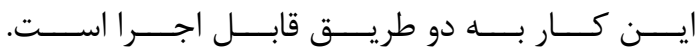

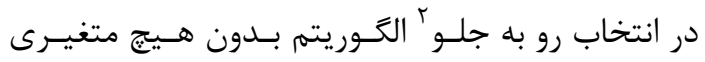

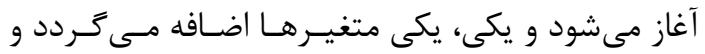

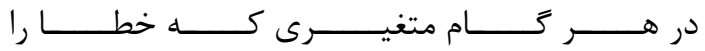

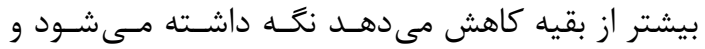

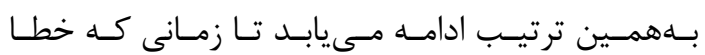
تغيير زيادى نكند ولى در انتخاب رو به عقب بَ الحَــوريته با تمام متغيرها آغـاز مسىشـود و يكى يكى يكى متغيــرهـا حذف مىشود و در هر مرحله متغيرى حذف مسى

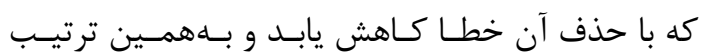

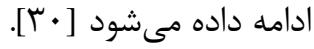

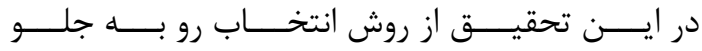

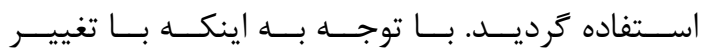

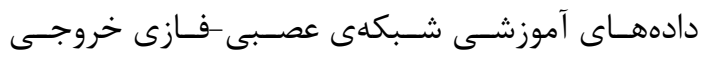

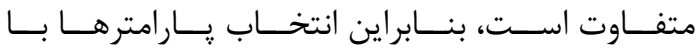

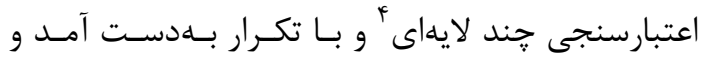

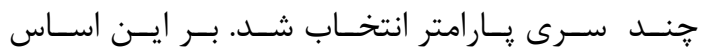

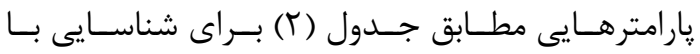

${ }^{1}$ Sequential Feature Selection

${ }^{2}$ Forward selection

${ }^{3}$ Backward selection

${ }^{4}$ Cross validation 
شناسـايى خودكـار نـوع وسـيلهى سـفر از دادههــGPS. ..

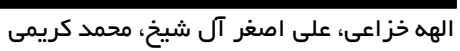

جدول ץ : يارامترهاى بهدست آمده براى استفاده از نقاط بحرانى

\begin{tabular}{|c|c|c|c|c|c|c|c|c|c|c|}
\hline $\begin{array}{l}: 3 \\
\vdots 3 \\
3 \\
3 \\
\vdots \\
: 3 \\
3 \\
3\end{array}$ & شيشينه & شتوسط & بيشينه & مترعت & نقاط بحت تعداد & تعداد نقاط & فاصلهى & فاصلهى & معيار & معيار \\
\hline 1 & & & $\checkmark$ & $\checkmark \checkmark$ & & & & & $\checkmark$ & $\checkmark$ \\
\hline$r$ & & & $\checkmark$ & $\checkmark$ & & & $\checkmark$ & & $\checkmark$ & \\
\hline r & & & $\checkmark$ & & $\checkmark$ & & & & $\checkmark$ & \\
\hline f & & $\checkmark$ & $\checkmark$ & $\checkmark$ & & & & & $\checkmark$ & \\
\hline$\Delta$ & & & $\checkmark$ & $\checkmark$ & & & & & $\checkmark$ & \\
\hline$q$ & $\checkmark$ & & & & & $\checkmark$ & & & $\checkmark$ & \\
\hline V & $\checkmark$ & & & $\checkmark$ & & & & $\checkmark$ & $\checkmark$ & \\
\hline
\end{tabular}

جدول ب : يار امتر هاى بهدست آمده براى استفاده از كل دادههاى GPS

\begin{tabular}{|c|c|c|c|c|c|}
\hline شار شاسه & سرعت متوسط & سيشينه & ميانگين زمان & انحراف معيار فاصلهها بين & عدم قطعيت \\
\hline 1 & $\checkmark$ & $\checkmark$ & & & \\
\hline$r$ & $\checkmark$ & $\checkmark$ & & & $\checkmark$ \\
\hline r & & $\checkmark$ & $\checkmark$ & & $\checkmark$ \\
\hline$f$ & & $\checkmark$ & $\checkmark$ & & \\
\hline$\Delta$ & $\checkmark$ & $\checkmark$ & $\checkmark$ & $\checkmark$ & \\
\hline$\varepsilon$ & $\checkmark$ & & $\checkmark$ & $\checkmark$ & \\
\hline V & $\checkmark$ & $\checkmark$ & $\checkmark$ & & $\checkmark$ \\
\hline
\end{tabular}

MATLAB بـراى آمــوزش شـبكه از نــرمافـزار 7.10

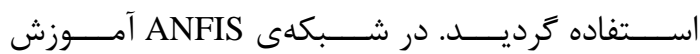
در دو روش يسانتشارخطا و روش تركيبى يـسانتشـار

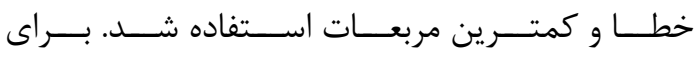

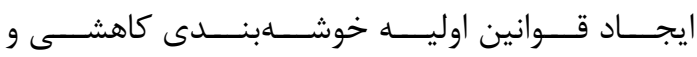

\begin{tabular}{|c|c|c|c|}
\hline ماشين سوارى & 1 & • & • \\
\hline اتوبوس & $\cdot$ & 1 & • \\
\hline يياده & • & • & 1 \\
\hline
\end{tabular}




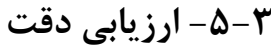

در اين تحقيق براى تحليل عملكرد و مؤثر بودن روش به كار گرفتهشده براى تعيين نوع وسيلهى سفر از

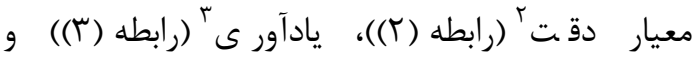

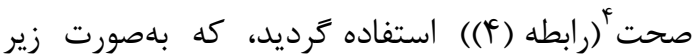
تعر يف مى

precision $=\frac{T P}{T P+F P}$

(r) رابطه

recall $=\frac{T P}{T P+F N}$

رابطه (r)

Accuracy $=\frac{T P+T N}{T P+T N+F P+F N}$

(ابطه (1)

كه يارامترها در اين فرمولها در يك دستهبندى

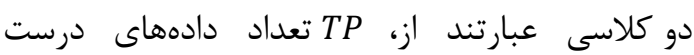
طبقهبندى شده در كلاس دو، FP تعداد دادههايى كه در كلاس اول قرار دارند و اشتباه طبقدبندى شدند، تعداد دادهايى است كه در كلاس دوم قرار دارند و

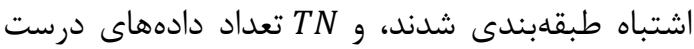
طبقهبندى شده در كلاس يك مى باشد. بهعبارتى مىتوان معيارها را بلصورت كيفى زير بيان نمود:

معيار دقت: نسبت تعداد دادههاى درست طبقهبندى شده به تعداد كل دادهاى طبقهبندى شده

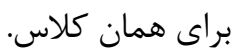

معيار يادآورى: نسبت تعداد دادهاى درست طبقهبندىشده به تعداد كل دادههاى مربوط به

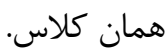

معيار صحت براى ارزيابى كل طبقهبندى انجامشده

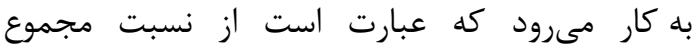
تمام دادهاى درست طبقهبندى بـده تمام كلاسها

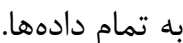

\footnotetext{
${ }^{2}$ Precision accuracy

${ }^{3}$ Recall accuracy
}

${ }^{4}$ Accuracy

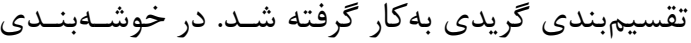

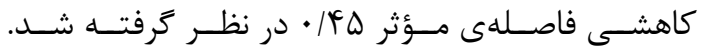

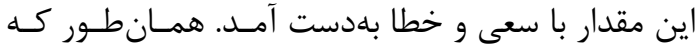

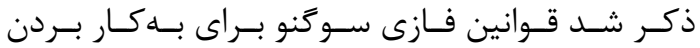
در اين شبكه ايجاد مى شود. قوانين سوكنو در دو دور حالت مرتبهى صفر و مرتبهى يك مورد بررسى قـرار كرفـت

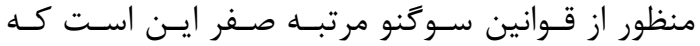

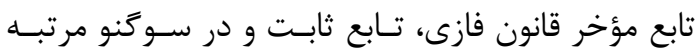
يك، تابع مؤخر تابعى خطى از ورودى هاست.

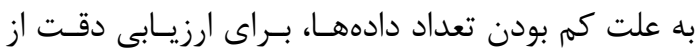

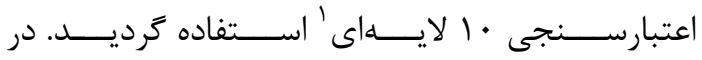

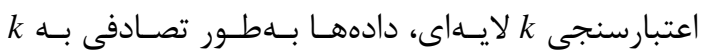
قسمت تقسيم مىشوند و سيس يكى قسـمت بــهـــــان دادههاى تست و 1 -1 قسمت باقيمانده بهعنوان دادههاى

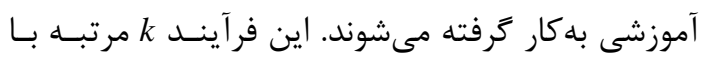
در نظر كرفتن يك قسمت متفاوت بــهـــــان دادهــاى

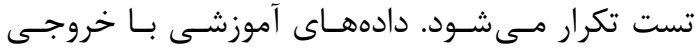
مربوط به هر كلاس بهطور جداثانه براى ايجـاد قـوانين

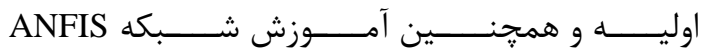
به كار ترفته مى شوند و يس از آموزش شبكه، دادههاى تست وارد هر سه سرى قوانين شناسايى نوع سفر شـده

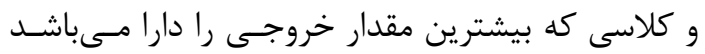

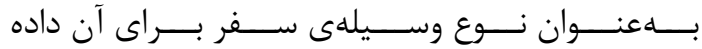

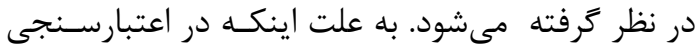
• الايهاى دادهها بهطور تصـادفى تقسـيم مسى تردنــد،

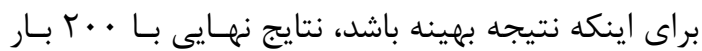
تكرار اعتبارسنجى • الايهاى بهدست آمد.

براى افزايش تفسيريذيرى قوانين بلهدستآمده از روش خوشهبندى كاهشى، از روش كاهش تعداد توابع عضويت فازى با در نظر كرفتن / /•= ג استفاده شد.

${ }^{1} 10 \_$Fold cross validation 


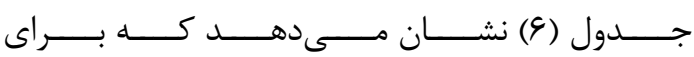

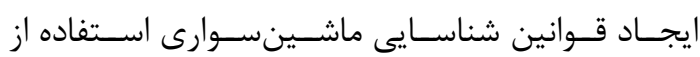

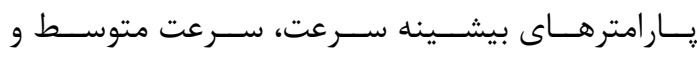

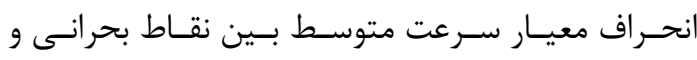

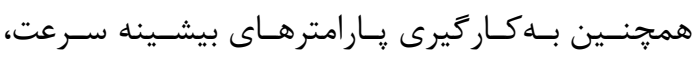

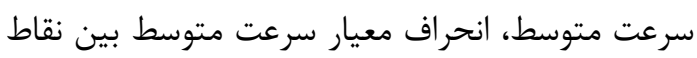

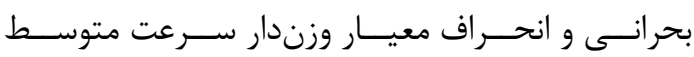

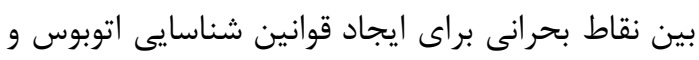

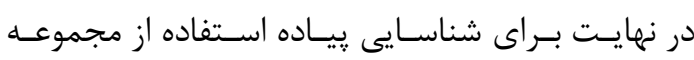

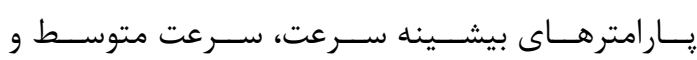

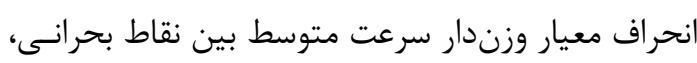

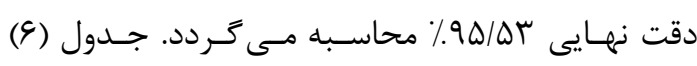

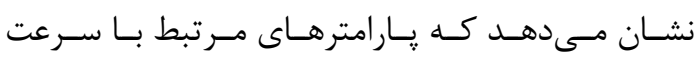

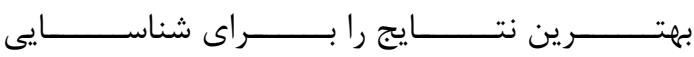

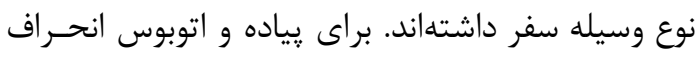

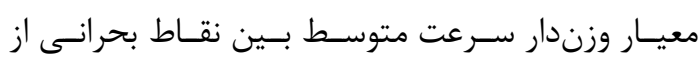

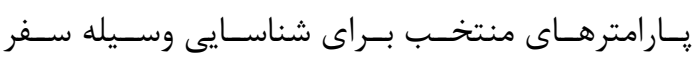

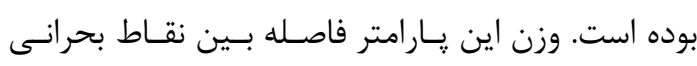

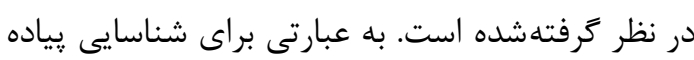

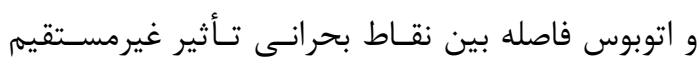

F F-F

كل نقاط GPS

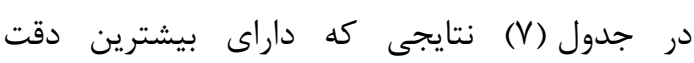

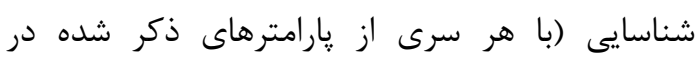

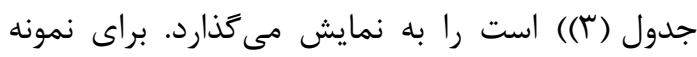

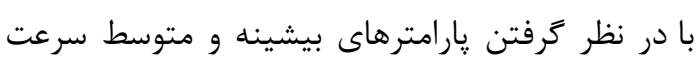

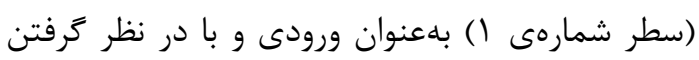

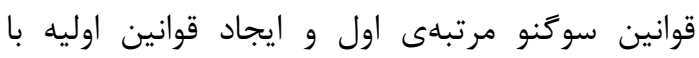

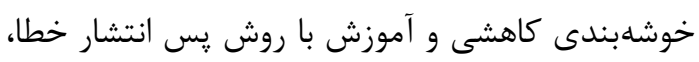

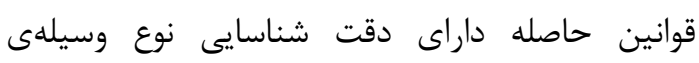

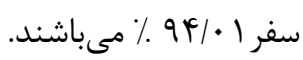

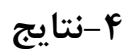

در ادامه به ارائه نتايج حاصل از شناسايى نوع وسيله

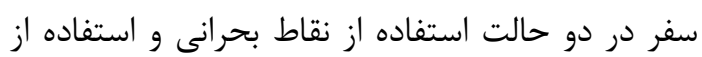
نقاط GPS يرداخته مىشود.

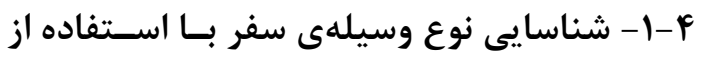

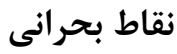

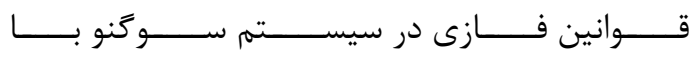

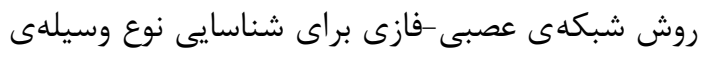

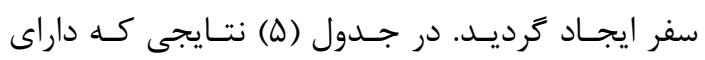

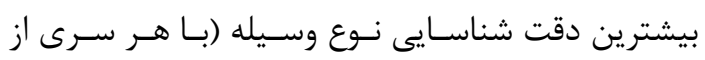

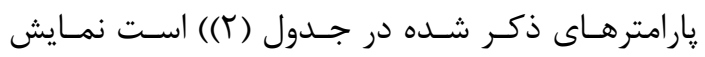

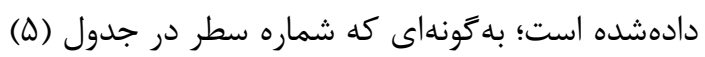

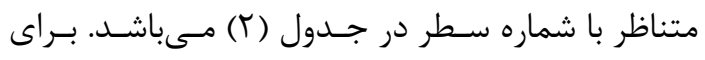

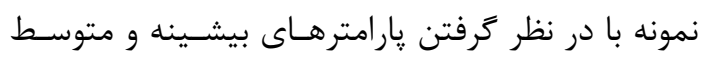
سرعت، انحراف معيار سرعت متوسط و انحــراف معيـار

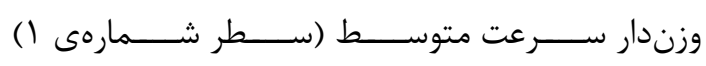

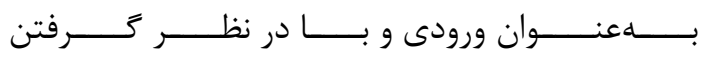

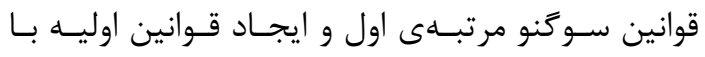

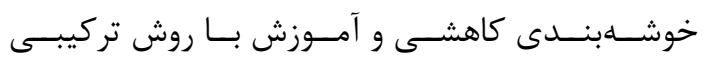

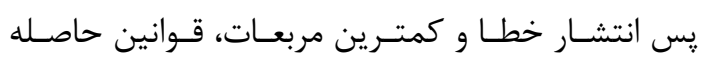

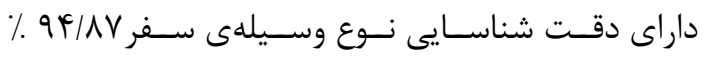

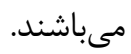
نتايج جدول (ه) براى حالتى است كه هر سه

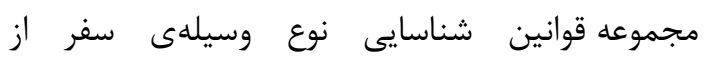

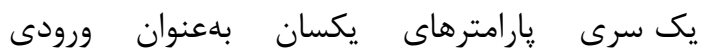

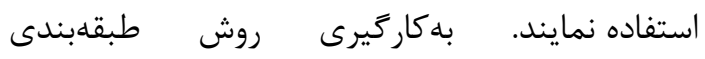

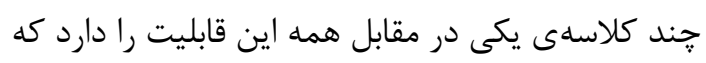

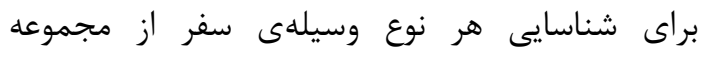

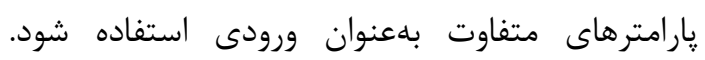

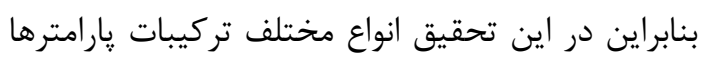

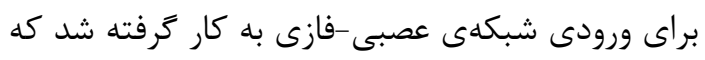

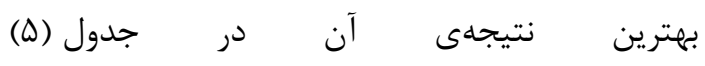
نمايش دادهده است. 
جدول ه : روشهاى منتخب و نتايج آنها براى حالات مختلف بررسىشده با نقاط بحر انى

\begin{tabular}{|c|c|c|c|c|c|c|c|c|}
\hline \multirow{2}{*}{ شارامتره } & \multirow{2}{*}{ ANFIS } & \multirow{2}{*}{ صحت (\%) } & \multicolumn{2}{|c|}{ اتوبوس } & \multicolumn{2}{|c|}{ ماشين سوارى } & \multicolumn{2}{|c|}{ ثياده } \\
\hline & & & يادآورى (.) & دقت (.) & يادآورى (.٪) & دقت (٪) & يادآورى (.) & دقت (.) \\
\hline 1 & $O n e^{a}-s u b^{b}-H y b^{c}$ & $q Y, \wedge V$ & $q \Delta, 19$ & 91,10 & $M M, F T$ & 94,90 & $1 \cdots$ & 99,97 \\
\hline r & Zero $^{\mathrm{d}}$-Grid ${ }^{\mathrm{e}}$-Hyb & $q\{, V 1$ & 94,9 & $q r, r q$ & $\wedge १, \& \wedge$ & (q) & $99,9 \%$ & $99, \% \varphi$ \\
\hline r & One-sub-Hyb & $\wedge \wedge, r \vee$ & $\Lambda T_{/} \wedge \Lambda$ & $\Lambda G, T Y$ & 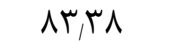 & $\Lambda T_{/} \mid \cdot$ & 91,9 & $9 \vee 91$ \\
\hline f & One-sub-BP ${ }^{f}$ & 94,49 & ( & $9 r, / F$ & $\wedge १, 9 \Delta$ & $q r, 4$. & $1 \cdots$ & 99,91 \\
\hline$\Delta$ & One-sub-Hyb & $q 4 / V$. & $q 4, \Delta$ & $q T, T r$ & 19, 94 & $q \pi, T$ & $1 \cdots$ & $99 / 94$ \\
\hline 4 & One-sub-BP & 91,90 & $\Lambda \Lambda, \vee G$ & $9 \cdot 111$ & $91, \vee \wedge$ & $9 \cdot 1 \cdot \cdots$ & 90,81 & $a \vee, r \Delta$ \\
\hline V & One-sub-BP & $q \pi, q$. & $19, \mu \mathrm{F}$ & $q \pi / \Delta \cdot$ & $91, V F$ & $\Lambda \wedge / \Delta)$ & 99,99 & $१ १, \Delta \Delta$ \\
\hline
\end{tabular}

Zero ${ }^{\mathrm{d}}$

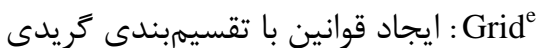

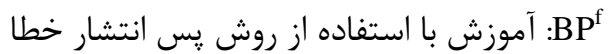

One : ايجاد قوانين با خوشهبندى كاهشى :Sub Hyb

جدول \& : بهترين نتيجه بهدست آمده از تركيبات مختلف يارامترها

\begin{tabular}{|c|c|c|c|c|c|c|}
\hline & سيشينه & سرعت & |نحراف معيار سرعت & سرعاف معيار وزندار & ياد آورى (.٪) & دقت (٪) \\
\hline ماشين سوارى & $\checkmark$ & $\checkmark \checkmark$ & $\checkmark$ & & 19,19 & $q \varphi, r y$ \\
\hline اتوبوس & $\checkmark$ & $\checkmark$ & $\checkmark$ & $\checkmark$ & $94,9 \wedge$ & $9 r_{1} \cdot 1$ \\
\hline يياده & $\checkmark$ & $\checkmark$ & & $\checkmark$ & $1 \cdots$ & ११,人५ \\
\hline صحت (.\%) & \multicolumn{6}{|c|}{$q \Delta / \Delta \mu \%$} \\
\hline
\end{tabular}

جدول V :روشهاى منتخب و نتايج آنها براى حالات مختلف بررسىشده با كل دادههاى GPS

\begin{tabular}{|c|c|c|c|c|c|c|c|c|}
\hline \multirow{2}{*}{ شناسه } & \multirow{2}{*}{ ANFIS } & \multirow{2}{*}{ صحت (\%) } & \multicolumn{2}{|c|}{ اتوبوس } & \multicolumn{2}{|c|}{ ماشين سوارى } & \multicolumn{2}{|c|}{ يِياده } \\
\hline & & & يادآورى (.) & دقت (.) & ياد آورى (٪) & دقت (.) & يادآورى (٪) & دقت (.\%) \\
\hline 1 & $O n e^{a}-s u b^{b}-B P^{c}$ & $9 q, 1$ & $q 4,81$ & $q \cdot, r \Delta$ & 19,99 & $q 4, \pi$. & $q V, T F$ & 99,99 \\
\hline r & One-sub-Hyb & 94,9 & $q F, \wedge f$ & $q \cdot, r \cdot$ & 19,94 & $q \varphi, \Delta F$ & $9 \vee, 11$ & $q 9, \Delta \varphi$ \\
\hline r & One-sub- BP & $q F_{1} \cdot v$ & $9 \mu, q V$ & $91, \cdot 4$ & $9 \cdot, 94$ & $q r_{1} \cdot \Delta$ & qV,Tr & $१ १, \wedge ६$ \\
\hline f & One-sub- BP & $q \mu, \Delta V$ & $q r, g 4$ & $q \cdot, v \cdot$ & $q \cdot, i v$ & $91, \wedge r$ & $q V, f$. & $१ १, \wedge \Delta$ \\
\hline$\Delta$ & One-sub-Hyb & $q \mu, \Delta q$ & $q \cdot, q 4$ & $q r, r \Delta$ & $9 r, 94$ & $q \cdot, \Delta \Delta$ & $q V, f p$ & $99,1 \vee$ \\
\hline$\varepsilon$ & One-sub- BP & 94,41 & $q 1, f q$ & $91,5 \wedge$ & 91,79 & $91,4 \pi$ & $q \vee, \uparrow \wedge$ & 99,19 \\
\hline V & Zero $^{\mathrm{e}}$-grid ${ }^{\mathrm{f}}-\mathrm{Hyb}$ & $q \pi, V D$ & 91,84 & $q r, r)$ c & qr, & $94, \pi 9$ & 94,94 & $91 / \cdot 1$ \\
\hline
\end{tabular}

آموزش با استفاده از روش تركيبى :Hyb

Zero ${ }^{\mathrm{e}}$

ايجاد قوانين با تقسيمبندى كرين مريدى : Grid
:One

:Sub

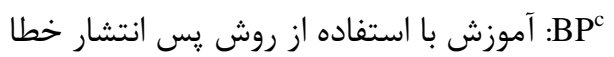


توقف بهترين نتايج را براى شناسايى نوع وسيلهى سفر

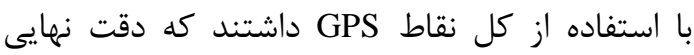

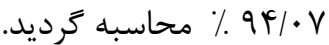

جدول (^) نشان مىدهد كه براى ايجاد قوانين

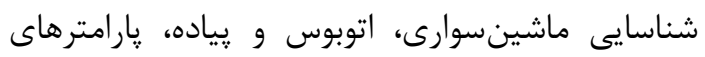
عدم قطعيت دقت افقى، بيشينه سرعت و ميانگَين زمان

جدول 1 : بهترين نتيجه بهدست آمده از تركيبات مختلف پارامترها

\begin{tabular}{|c|c|c|c|c|c|}
\hline & تويانكين زمان & بيشينه سرعت & عدم قطعيت افقى & 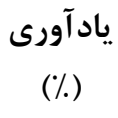 & دقت (\%) \\
\hline ماشين سوارى & $\checkmark$ & $\checkmark \checkmark$ & $\checkmark$ & $9 \cdot 94$ & $9 q_{1} \cdot \Delta$ \\
\hline اتوبوس & $\checkmark$ & $\checkmark$ & $\checkmark$ & $9 \pi, 9 V$ & $91, \cdot 4$ \\
\hline بياده & $\checkmark$ & $\checkmark$ & $\checkmark$ & qV,Tr & $99, \wedge 9$ \\
\hline صحت (.) & \multicolumn{5}{|c|}{$q \varphi / \cdot V \%$} \\
\hline
\end{tabular}

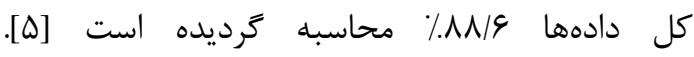

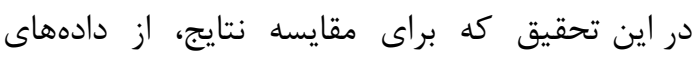

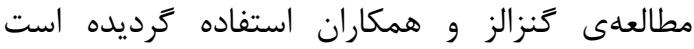
با دستيابى به دقت به/هو ٪ ٪ در حالت استفاده از

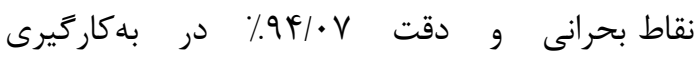
كل داده ها، نشان داده شد كانى ده سيستم استنتاج عصبى-فازى روشى مناسب و كارا براى شناسايى

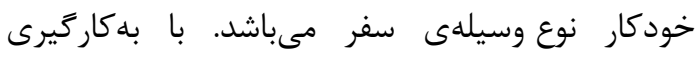

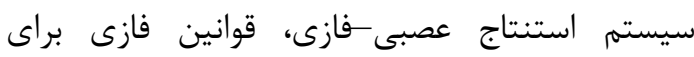
شناسايى نوع وسيلهى سفر استخراج كرديد و واسئ

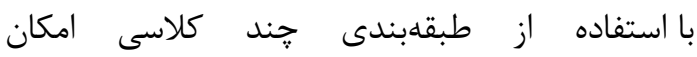

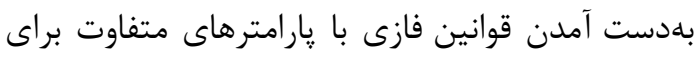
هر نوع وسيلهى سفر فراهم گرديد. لازم به ذكر است

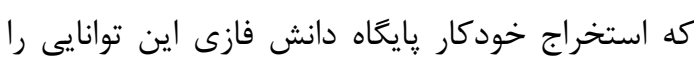

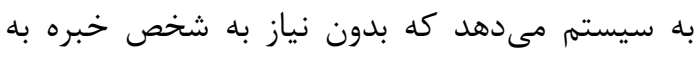

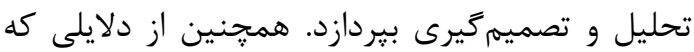
شبكهى عصبى-فازى قادر به تشخيص دقيق نوع

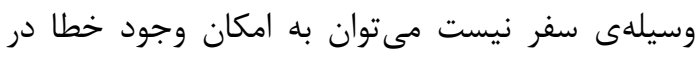
دادهها و تعداد كم سفرها اشاره نمود. نيست

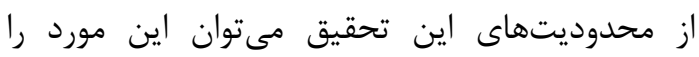

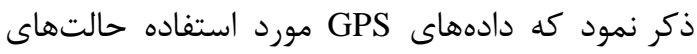
مختلف سفر بهصورت دستى تقسيمبندى شده بود بودند و وادهاى هر سفر شامل يك نوع وسيلهى حمل و نقل بود.

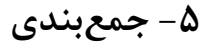

در اين تحقيق بابهاركيرى سيستم استنتاج

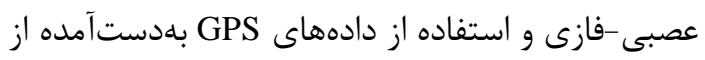

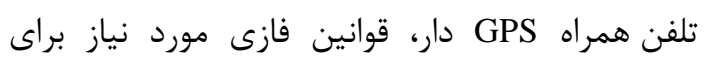
شناسايى نوع وسيلهى سفر از دادهها استخراج كرديد.

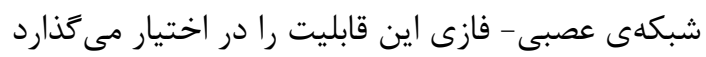

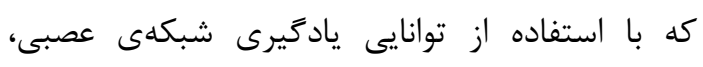

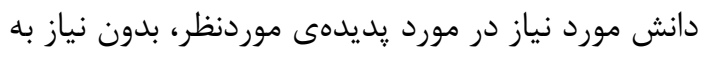
شخص خبره، در قالب قوانين مناسب بيان كردد.

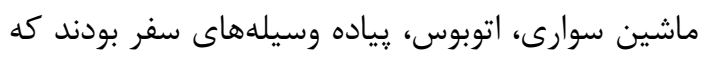

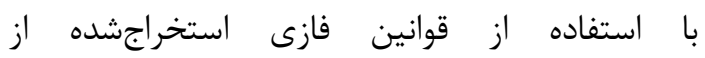
دادههاى GPS بلصورت خودكار شناسايى كرديدند.

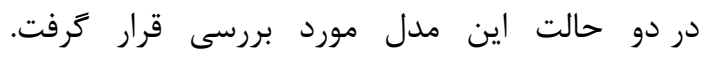

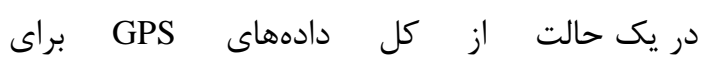

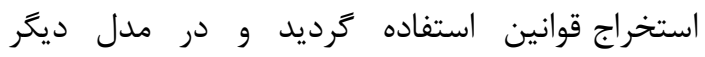
بلمنظور كاهش نقاط ثابت GPS انتقالى به سرور و و صرفهجويى در مصرف انرزى باترى، بهنياى باند شبكه و

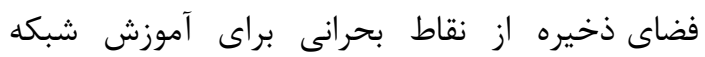

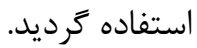

در مطالعهى انجامشده توسط كنزالز و همكاران كه

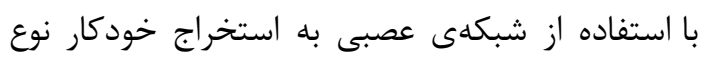

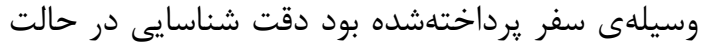

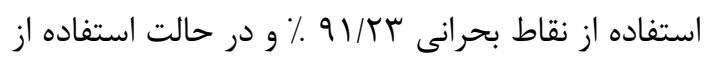


بنابراين پِيشنهاد مىشود روى روشهايى كه بتوان

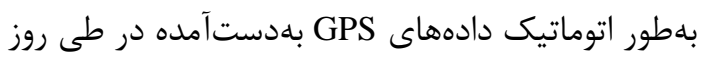
را به قسمتهايى كه شامل يك نور أومائي دادهاى وسيلهى سفر هستند تقسيم نمايد، كار شود. همجنين از آنجايى كه دادهها داراى خطا مىباشند بايد با روشهايى ميزان

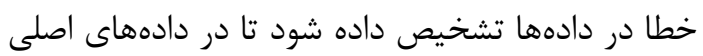
حذف يا اصلاح گردد كه بتوان با روشهاى يادگيرى داده ماشين نوع وسيلهى سفر بلدرستى تشخيص داده شود. سباسگزارى

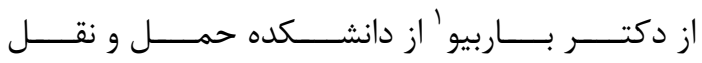

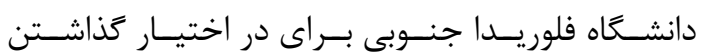
دادهاى مورد نياز اين تحقيق سياسگزاريم. 
[1] Stopher, P., \& Greaves, S. P., "Household travel surveys: Where are we going?".Transportation Research Part A, Vol. 41, pp. 367-381, 2007.

[2] Murakami, E., Wagner, D. P., Neumeister, D. M. ,. "Using Global Positioning Systems and Personal Digital Assistants for Personal Travel Surveys in the United States". Grainau, Germany. : International Conference on Transport Survey Quality and Innovation, 1997.

[3] Murakami, E. and D. P.Wagner. "Can using global positioning system (GPS) improve trip reporting?" Transportation Research Part C, Vol. 7(2/3), pp. 149-165, 1999.

[4] Stenneth, L., Wolfson, O., Yu, P. S., \& Xu, B., "Transportation mode detection using mobile phones and GIS information". ACM SIGSPATIAL GIS-Chicago, IL, USA, 2011.

[5] Gonzalez,P, Weinstein,J. , Barbeau,S., Labrador, M. , Winters,P. , Georggi ,N., Perez,R., "Automating mode detection for travel behaviour analysis by using global positioning systems enabled mobile phones and neural networks". IEEE, Intelligent Transport Systems, IET, Vol. 4, pp. 37- 49. 1751-956X, 2010.

[6] Gong,H., Chen,C. , Bialostozky,E. , Lawson,C.T., "A GPS/GIS method for travel mode detection in New York City". Computers, Environment and Urban Systems, Vol. 36, pp. 131-139, 2012.

[7] Bolbol,A. , Cheng,T., Tsapakis,I. , Haworth,J., "Inferring hybrid transportation modes from sparse GPS data using a moving window". 6, Computers, Environment and Urban Systems, Vol. 36, pp. 526-537, 2012.

[8] Zheng, Y., Chen, Y., Li, Q., Xie, X., \& Ma, W., "Understanding transportation modes based on GPS data for Web applications". 4 ACM Transaction on the Web, Vol. 1, pp. 1-36, 2010.

\section{مراجع}

[9] Reddy, S., Mun, M., Burke, J., Estrin, D., Hansen, M., Srivastava, M., "Using Mobile Phones to Determine Transportation Modes". 2, ACM Transactions on Sensor Networks, Vol. 6, 2010.

[10] Schüssler, N.,\& Axhausen,K.W. "Processing GPS Raw Data Without Additional Information". Transportation Research Record: Journal of the Transportation Research Board, 2105, pp. 28-36, 2009.

[11]Iljecki, F.,, Ledoux, H. and Van Oosterom, P., "Transportation mode-based segmentation and classification of movement trajectories“, International Journal of Geographical Information Science, Vol. 27(2) ,pp. 385-407,2013.

[12] Waga, K., Tabarcea, A., Chen, M. and Fränti, P., "Detecting movement type by route segmentation and classification," Collaborative Computing: Networking, Applications and Worksharing (CollaborateCom), 2012 8th International Conference on. IEEE, 2012.

[13]Rudloff , C. and Ray, M., "Detecting Travel Modes and Profiling Commuter Habits Solely Based on GPS Data, "In Proceedings of the Transportation Research Bwoard 89th Annual Meeting, Washington, DC, USA, 10-14 January 2010.

[14] Broach, J.; McNeil, N.W.; Dill, J., "Travel Mode Imputation Using GPS and Accelerator Data from Multi-Day Travel Survey.," In Proceedings of the Transportation Research Board 93rd Annual Meeting, Washington, DC, USA, 12-16 January 2014.

[15]Xiao, G., Zhicai J., and Jingxin Gao, "Travel Mode Detection Based on Neural Networks and Particle Swarm Optimization ," Information Vol.6(3), pp: 522-535,2015.

[16] Wang, L., "Fuzzy Systems and Fuzzy Control", translated by Teshne Lab, M., 
Ofyuni , D., Safarpour, N., Khaje Nasir Toosi University Press, 2010

[17] Horikawa,S., T.,Furuhashi, Y.,Uchikawa , "On fuzzy modelling using fuzzy neural networks with the back-propagation algorithm”. 5, IEEE Trans Neural Netw, Vol. 3, pp. 801-806. doi:10.1109/72.159069, 1992.

[18]Lin, C.T., C.S.G.,Lee. "Neural-networkbased fuzzy logic control and decision system". 12, IEEE Trans Comput C, Vol. 40, pp. 1320-1336, 1991.

[19] Jang,J.S.R. “ANFIS: Adaptive-NetworkBased Fuzzy Inference Systems". IEEE Transaction on Systems, Man, and Cybernetics 23, pp. 665-685, 1993

[20] Gonzalez, P., Weinstein, J., Barbeau, S., Labrador, M., Winters, P., Georggi ,N., Perez,R., "Automating Mode Detection Using Neural Networks and Assisted GPS Data Collected Using GPS-enabled Mobile Phones". 15th World Congress on Intelligent Transportation Systems, 2008.

[21]Barbeau, S., Labrador, M., Perez, A., Winters, P., Georggi, N., Aguilar, D., Perez, R. "Dynamic Management of RealTime Location Data on GPS-enabled Mobile Phones". UBICOMM 2008 - The Second International Conference on Mobile Ubiquitous Computing, Systems, Services, and Technologies, Valencia, Spain, September 29 - October 4, 2008.

[22] Vieira,J. , M.,Dias, F.A.,Mota. "NeuroFuzzy Systems: A Survey". 5th WSEAS NNA International Conference on Neural Networks and Applications, 2004.

[23] Hammouda, K. "A comparative study of data clustering techniques". Citeseer, Vol. 625,2000 .

[24] Chiu. "fuzzy model identification based on cluster estimation". Journal of Intelligent \& Fuzzy Systems, Vol. 2, pp. 267-278, 1994.

[25] Wu, Y., et al. "Fuzzy Logic and Neurofuzzy Systems: A Systematic Introduction". 2, International Journal of Artificial Intelligence and Expert Systems (IJAE),
Vol. 2, 2011.

[26] Setnes, M., et al. "Similarity Measures in Fuzzy Rule Base Simplification”. 3, IEEE Transactions on systems, man, and cybernetics part b cybernetics, vol. 28, 1998.

[27] Chen, M.Y , D.A., Linkens. "Rule-base self-generation and simpli\&cation for datadriven”. Fuzzy Sets and Systems, Vol. 142, pp. $243-265,2004$.

[28] Aly, M. "Survey on Multi-Class Classification Methods". Technical Report, Caltech, USA, 2005.

[29] Jang, J.S.R. "Input selection for ANFIS learning”. IEEE, pp. 1493-1499. 10987584, 978-1-4244-3596-8, 1996.

[30]Ladha, L., Deepa, T. "Feature selection methods and algorithms". 5, International Journal on Computer Science and Engineering (IJCSE), Vol. 3. ISSN:09753397, 2011. 


\title{
Automatic mode detection in transportation using GPS data from mobile devices and neuro -fuzzy system
}

\author{
Elahe Khazaei ${ }^{1}$, Ali Asghar Alesheikh ${ }^{2}$, Mohammad Karimi ${ }^{3}$ \\ 1- PHD student in GIS, Faculty of Geomatics Engineering, K.N. Toosi University of Technology \\ 2- Professor, GIS Department, Faculty of Geodesy and Geomatics Eng. K.N. Toosi University of Technology \\ 3- Assistant professor, GIS Department, Faculty of Geodesy and Geomatics Eng. K.N. Toosi University of Technology
}

\begin{abstract}
Cognition of travel mode and travel demand is of prime importance to transportation communities and agencies in every country. If the precise transportation modes of individual users are recognized, a more realistic travel demand can be considered. Also, in location-based service, the knowledge of a traveler's transportation mode is applied to send targeted and customized informative advertisements. This study examines the feasibility of using a neuro-fuzzy inference system to automatically detect the mode of transportation from GPS data collected by GPS-enabled mobile phones. To achieve this, the knowledge was extracted in the form of fuzzy rules from the data and, then, the rules are being used for determination of transportation's mode. For this purpose, the model was examined in two cases. In the first case, all GPS data from mobile devices were used, while in the second case the critical point algorithm was exercised. In addition to reducing the size of required GPS datasets, the critical point algorithm decreases data collection cost and saving mobile phone resources such as its battery life. The results showed that the suggested model have the capability of detecting a transportation mode with 94/1 percent accuracy in case of using all GPS data and 95.5 percent accuracy in case of using critical points.
\end{abstract}

Key words: Neuro-fuzzy system, Transportation Mode detection, Critical points, GPS data.

Correspondence Address : GIS Department, Faculty of Geodesy and Geomatics Eng. K.N. Toosi University of Technology, Tehran, Iran.

Tel : +98 9354281500

Email: Ekhazaei@mail.kntu.ac.ir 